\title{
FROM TRIPS TO FTAs AND BACK: \\ RE-CONCEPTUALISING THE ROLE OF A MULTILATERAL IP \\ FRAMEWORK IN A TRIPS-PLUS WORLD
}

\begin{abstract}
Henning Grosse Ruse-Khan*
\section{ABSTRACT}

International intellectual property (IP) law has shifted focus after the WTO Agreement on Trade Related Aspects of Intellectual Property Rights (TRIPS) set out comprehensive global standards about 20 years ago: since the mid-nineties, most international rule-making to protect and enforce IP rights comes in form of bilateral or regional agreements, here generally referred to as Free Trade Agreements (FTAs). As multilateral solutions have been increasingly difficult to agree upon, the world has witnessed an unprecedented proliferation of these FTAs. The wide range of issues covered by FTAs allow countries which are otherwise reluctant to agree to increases in IP protection to accept them because of trade-offs - such as obtaining (or avoid losing) preferential access to the markets of their FTA partners. Because of these trade-offs, most FTAs with IP provisions contain obligations on the protection and enforcement of IP that set significantly higher standards than those of the TRIPS Agreement, commonly referred to as 'TRIPS-plus' standards.
\end{abstract}

Most commentators lament this development since TRIPS-plus IP obligations frequently undermine the ability of WTO Members to rely on the policy space and flexibilities TRIPS leaves to design national IP laws in light of domestic needs. UN human rights organs have considered such flexibilities critical for access to medicines and other essential goods. In this article, I will make a case for the continued relevance of the TRIPS Agreement as an overarching, multilateral framework for TRIPS-plus FTAs. My argument is based on the utilitarian objectives of IP protection that WTO Members have agreed to in Article 7 TRIPS. For the purpose of treaty law, these objectives form, together with the public interest principles expressed in Article 8 TRIPS, the agreement's object and purpose. In the 2001 Doha Declaration on TRIPS and Public Health, all WTO Members highlighted the principal role of these norms for interpreting and implementing TRIPS in a way that allows to give effect to public interests, such as access to medicines.

The role of Articles 7 and 8 however goes beyond treaty interpretation and implementation: I argue that these norms are of integral character - such that provisions essential for giving effect to TRIPS' object and purpose cannot, as a matter of treaty law, be derogated from in bilateral or regional agreements amongst WTO Members. The article intends to show this with reference to the negotiation history of Articles 7 and 8, the utilitarian objectives and public interest principles for IP protection they set out, and the recognition a common object and purpose warrants under general international law principles on inter-se modifications of multilateral treaties. For TRIPS-plus obligations in FTAs, this means that they need to respect TRIPS provisions which are essential to give effect to the objectives and principles expressed in Articles 7 and 8 . However, because these objectives and principles leave significant freedom to WTO Members in deciding on how to protect public interests and on the most appropriate 
balance between IP protection and access, they at best serve as a loose constitutional frame for TRIPS-plus protections in bilateral and regional agreements. Usually, they will allow FTA partners to re-balance TRIPS-plus protections with suitable exceptions or other limitations to IP protections when implementing TRIPS-plus FTA rules in their national laws.

\section{OUTLINE}

1. Introduction

2. The Context: Problems Arising from Comprehensive TRIPS-plus Provisions as Trade-Offs in Bilateral and Regional Agreements

3. Articles 7 and 8 TRIPS as Patrons of a Flexible Global IP Framework

3.1 The Basic Idea of Tailoring IP protection to Domestic Needs, and Mindful of the Wider Public Interest

\subsubsection{Negotiation History}

3.1.2 Balancing Objectives and Public Interest Principles: Exploring Possible Meanings

3.2 Articles 7 and 8 in the Doha Declaration on TRIPS and Public Health

3.3 Discretion for Balancing in Domestic Implementation of TRIPS

3.4 Collective Calls to Retain and Protect TRIPS Flexibilities

4. Limits on Modifying TRIPS Inter-Se

4.1 More Extensive IP Protection under Article 1 (1) TRIPS

4.2 Inter-se Modifications under Article 41 VCLT

4.2.1 Applicability in the WTO Context

4.2.2 Operationalising the Principles in Article 41 VCLT

4.2.2.1 Affecting rights or obligations of other WTO Members

4.2.2.2 Undermining the effective operation of TRIPS' object and purpose: the nature of TRIPS obligations

5. Conclusion: Arguing for a more Resilient Multilateral IP Framework

\section{Introduction}

The international protection of intellectual property (IP) has developed significantly since the Uruguay Round of trade negotiations brought about the World Trade Organization (WTO) and its Agreement on Trade Related Aspects of Intellectual Property Rights (TRIPS). ${ }^{1}$ That development is astonishing, since the TRIPS Agreement in itself marked a milestone in global

\footnotetext{
Reader in International and European Intellectual Property Law, King's College - University of Cambridge; External Research Fellow at the Max Planck Institute for Innovation and Competition (Munich). I owe thanks to my colleagues at the Lauterpacht Centre for International Law at Cambridge, to the participants of the IP Forum at Queen Mary University of London, and to the two anonymous reviewers, for their comments and suggestions. Of course, all errors remain mine.

${ }^{1}$ Marrakesh Agreement establishing the World Trade Organization (WTO Agreement), (Marrakesh, 15 April 1994, 1867 UNTS 154) and Agreement on Trade Related Aspects of Intellectual Property Rights (TRIPS), Annex 1C of the WTO Agreement (Marrakesh, 15 April 1994, 1869 UNTS 299).
} 
IP norm-setting, and still constitutes the single most important treaty in the multilateral IP framework. TRIPS establishes a comprehensive set of obligations to essentially protect all types of IP rights, updates levels of protection to fit technological advances until the early nineties, and introduces for the first time a full range of rules on the enforcement of IP rights in domestic legal systems. Last but certainly not least, as part of WTO law, TRIPS subjects IP-related obligations (including to comply with the two main preceding international IP treaties) ${ }^{2}$ to WTO dispute settlement. For these reasons alone, TRIPS serves as the core reference point in analysing current international IP law and policy.

While these reasons are well understood, TRIPS should further be recognised for serving as the first global expression of an agreed nature, function, and purpose of IP rights. In its Preamble, all WTO Members emphasise 'that intellectual property rights are private rights' - but in the following paragraph acknowledge 'the underlying public policy objectives of national systems for the protection of intellectual property, including developmental and technological objectives'. These two directly connected considerations of the Preamble indicate how the international IP system is designed to operate: in accordance with the standards set out in TRIPS, WTO members are obliged to grant and protect private rights for owners of IP from all other WTO members. These private rights provide their owners with exclusive control to prevent others (such as users or competitors) from exploiting the protected subject matter (such as works, inventions, or marks as indicators of commercial origin). This arguably unparalleled global system of protection for private rights however is not an end in itself, nor is it based on a commonly accepted natural rights logic, or on agreed ideas of a sacrosanct nature of property. In TRIPS, WTO Members also agree to limit IP rights in terms of subject matter, scope, by means of specific exceptions, state-granted allowance for use (compulsory licences), and in their duration. On the domestic level, granting and protecting IP by means of private rights usually serves public policy objectives - such as promoting creativity and innovation, access to essential goods and services, as well as the transfer of technology. WTO Members acknowledge these public policy objective in the TRIPS Preamble - which hence serves as a first indicator that TRIPS conceptualises IP protection as inherently utilitarian. In most countries that implement TRIPS, it is meant to fulfil a social function and should promote broader welfare objectives.

This utilitarian approach is not only reflected in the language of the TRIPS preamble, and represents the overall most commonly accepted objective of IP protection in state practice and academic scholarship. ${ }^{3}$ Most importantly for the purposes of this analysis, it finds expression

\footnotetext{
${ }^{2}$ Paris Convention on the Protection of Industrial Property (PC) (Paris, 20 March 1883, last revised at Stockholm on 14 July 1967 and amended in 1979, 828 UNTS 306) and Berne Convention on the Protection of Literary and Artistic Works (BC) (Berne, 9 September 1886, last revised at Paris on July 241971 and amended in 1979, 1161 UNTS 30).

${ }^{3}$ See for example Article I, Section 8, Clause 8 of the United States Constitution, which empowers the United States Congress '[t]o promote the Progress of Science and useful Arts, by securing for limited Times to Authors and Inventors the exclusive Right to their respective Writings and Discoveries' (emphasis added). Arguments for enhancing welfare, or more specifically fostering advances in technology, science and cultural productions through incentives based on IP rights, are often explicit or implicit in IP legislation - see for example recital 4 of the Directive 2001/29/EC of the European Parliament and of the Council of 22 May 2001 on the harmonisation of certain aspects of copyright and related rights in the information society (Official Journal L 167, 22 June 2001). For a comprehensive discussion on various justifications (and in favour of an instrumentalist, utilitarian approach),
} 
in the object and purpose of the TRIPS Agreement. As discussed further in section 3, with Article 7 TRIPS, entitled 'Objectives', all WTO Members agree that IP protection and enforcement should contribute to various societal goals, and overall promote 'social and economic welfare'. Section 3 also shows how the somewhat convoluted accumulation of more immediate aims and long-term goals expressed in Article 7 can be operationalised within the international IP system: together with the public interest 'Principles' embodied in Article 8 TRIPS, they form the object and purpose of TRIPS which guides the interpretation and implementation of all of its provisions. In paragraph 4 and 5 a) of the Doha Declaration on TRIPS and Public Health, ${ }^{4}$ all WTO Members agreed to this essential guiding role of Articles 7 and 8, and emphasised this as one of the core elements that allows WTO Members to pursue other public interests, such as access to medicines.

Section 4 then builds on the widely accepted role of Articles 7 and 8 described above in order to assess the article's principal research question: what role, if any, do these provisions play in an increasingly fragmented international IP system that is driven by bilateral and regional agreements which significantly advance the levels of IP protection beyond those agreed in TRIPS? These so called 'TRIPS-plus' protections are frequently criticised because they undermine the ability of WTO Members to rely on the policy space and flexibilities TRIPS leaves to design national IP laws in light of domestic needs. As section 2 discusses in detail, International Organizations such as the United Nations (UN) and the World Health Organization (WHO), national parliaments, Non-Governmental Organizations (NGOs) and academic scholarship all lament the continued expansion of TRIPS-plus standards. They often point to duties to respect, protect, and fulfil (socio-economic) human rights, commitments under international bio-diversity treaties, or concepts of sustainable development which are arguably implicated by TRIPS-plus. What however is missing so far is an analysis of the potential role of the existing multilateral IP framework, namely the TRIPS Agreement and its Objectives and Principles, in safeguarding the policy space it provides for WTO Members in designing their domestic IP systems. This article aims to fill this gap.

In this context, my main argument advanced in section 4 is that as essential expressions of TRIPS' object and purpose, Articles 7 and 8 have an integral character. Integral in the sense that provisions of TRIPS which are decisive to achieve the utilitarian objectives and public interest principles these Articles set out cannot be derogated from in bilateral or regional agreements amongst WTO Members. This argument has its foundation in the idea that there are limits on the extent to which some of the parties to a contract can later modify the contract inter-se: for example, when rights of other contracting parties are affected, or when a common objective of the first contract is undermined. Building on the role of the TRIPS' objectives and principles developed in section 3, international treaty law imposes limits on the extent to which WTO Members can derogate from TRIPS provisions, including its flexibilities. After

see Drahos, 1996; and Fisher, 2001 (who takes a fresh look at four central approaches, identifying core flaws in all of them as all-embracing justifications). See also Hughes, 1988 and Spence, 2002. Of course, the difficulty with a utilitarian approach is to in fact determine a causal link between a particular form and level of IP protection and welfare gains - but this is exactly why section 3 argues that such determinations can, if at all, only be made context-specific, and should be left, as much as possible, to domestic decision-makers.

${ }^{4}$ Doha Declaration on the TRIPS Agreement and Public Health (Doha Declaration) (Doha, 14 November 2001, $\mathrm{WT} / \mathrm{MIN}(01) / \mathrm{DEC} / 2)$. 
discussing TRIPS-specific conflict norms, section 4 considers the general international law principles that govern inter-se modifications of a treaty. Together with the function Articles 7 and 8 perform for the interpretation of bilateral and regional agreements amongst WTO Members, the image of a resilient multilateral system of IP protection emerges: A multilateral framework which retains a right for WTO Members to re-balance their domestic IP systems so as to promote utilitarian objectives on the domestic level.

My main conclusion in section 5 therefore is that the fragmented advances of IP protection via bilateral and regional agreements need to respect TRIPS provisions which are essential to give effect to the objectives and principles set out in the TRIPS Agreement. However, because there is significant freedom for WTO Members in deciding how to protect public interests, and on the most appropriate balance between IP protection and access, the object and purpose of TRIPS at best provides a loose constitutional framing for TRIPS-plus protections in bilateral and regional agreements. Usually, it will simply allow contracting states to re-balance TRIPS-plus protections by introducing suitable exceptions and other limitations to IP protection when implementing international IP obligations in their national laws. More generally, such a right to re-balance is limited to the range of acceptable understandings of the essential TRIPS provisions that the customary rules of treaty interpretation, giving due regard to the object and purpose of a treaty, can support. The flexibility and context-specificity inherent in the object and purpose of TRIPS make it very difficult to argue that other WTO Members have rights to demand specific changes to the implementation of IP obligations in bilateral and regional agreements.

Before these principal arguments are developed in sections 3 to 5, section 2 below sets out the context that describes the development towards a fragmented international IP system, primarily due to the proliferation of bilateral and regional agreements that, inter alia, cover IP.

\section{The Context: Problems Arising from Detailed TRIPS-plus Provisions as Trade-Offs in Bilateral and Regional Agreements}

In a post-TRIPS environment, international IP law has, despite some early and some more recent multilateral advances negotiated at the World Intellectual Property Organization (WIPO) in the field of copyright, ${ }^{5}$ primarily developed via a network of bilateral and regional agreements. These range from international investment- and free trade agreements (IIAs, FTAs), via treaties on development cooperation, to comprehensive regional integration accords - and, for the sake of simplicity, will be referred to here simply as 'FTAs'. For reasons explained below, since the mid-nineties, countries interested in further increasing IP standards have had much more success in negotiating IP (as well as other trade and trade-related issues)

\footnotetext{
${ }^{5}$ See for example the WIPO Copyright Treaty (WCT) (Geneva, 20 December 1996, 2186 UNTS 121), and more recently for example Marrakesh Treaty to Facilitate Access to Published Works for Persons who are Blind, Visually Impaired, or Otherwise Print Disabled (Marrakesh Treaty) signed at Marrakesh, 27 June 2013 http://www.wipo.int/treaties/en/text.jsp?file id=301016
} 
in fora outside the WTO and WIPO. ${ }^{6}$ With multilateral solutions increasingly difficult to achieve, the world has therefore witnessed an unprecedented proliferation of FTAs.

A brief look at the current numbers of bilateral and regional agreements provides a good indication of the scale of this phenomenon: On its website, the WTO, as of mid-2017, counts some 659 notifications of so called 'regional trade agreements' (RTAs) that had been received by the GATT/WTO. ${ }^{7}$ Of these, 445 are in force. What all RTAs in the WTO have in common is that they are reciprocal trade agreements which further liberalise trade between two or more countries. As the data from WIPO below suggests, quite a lot of these agreements contain a chapter with obligations for the protection and enforcement of IP rights. Typically, IP obligations are requested for the benefit of IP-dependent export industries of one (or more) of the trading partners - and agreed by the other one(s) in exchange for commitments which benefit its own export industries, such as enhanced market access for goods or services. ${ }^{8}$ In 2017, WIPO in turn counts 572 IP-related bilateral treaties - a significant portion of which are again agreements where enhanced IP protection and enforcement commitments accepted by one side function as a trade-off for concessions made by the other side. ${ }^{9}$

While this is not the place to question the overall welfare effects of such trade-offs or to engage in a detailed assessment of whether the benefits outweigh the losses that follow from such political decisions, the sustainability of such an approach from a long-term, global perspective generally appears doubtful: A trade concession obtained for agreeing to stronger IP rights usually derives its main economic value from being exclusive to the export industry of the country receiving this concession. Once the same or a similar concession is granted to competitors in third countries, the relative advantage is gone. That is why WTO law allows, under certain conditions, to shield further trade liberalisation in form of such concessions from the application of the most-favored-nation (MFN) principle. ${ }^{10}$ In fact, the MFN exception creates the principal raison d'être for negotiating agreements - like RTAs and Customs Unions - that liberalise trade beyond the multilateral WTO standards. Once however the IP-demanding country grants equivalent trade concessions to other countries, the country which had agreed to higher IP standards risks to lose the economic benefits it hoped to obtain from the trade concession it initially obtained. This form of preference erosion ${ }^{11}$ calls the rationale for agreeing to higher IP standards as a part of a trade-off deal - and thereby the overall concept of IP law-making in the trade context - into question. In addition, IP standards driven by the export needs of another country hardly ever are those most suited to the domestic needs of innovators, creators, users and the general public.

\footnotetext{
${ }^{6}$ On the notion of 'regime shifting' in international IP law see generally Helfer, 2004; and Raustiala, 2006.

See the WTO website on what it defines as 'regional trade agreements' at http://www.wto.org/english/tratop e/region e/region e.htm (accessed 17 September 2017).

${ }^{8}$ Correa et al, 2013, 878 .

9 See the WIPO lex website on IP-related bilateral treaties at http://www.wipo.int/wipolex/en/treaties/index bilateral.jsp (accessed 17 September 2017).

${ }^{10}$ See Articles I and XXIV of the General Agreement on Tariffs and Trade 1994 (GATT) (Marrakesh, 15 April 1994, 1867 UNTS 190).

${ }^{11}$ On the concept of preference erosion see generally Hoekman et al, 2006.
} 
Of course, the general idea of negotiating IP as a part of a broader deal is hardly anything new: the WTO TRIPS Agreement is generally viewed as the beginning of an era where IP is regulated from a trade perspective. ${ }^{12}$ It nevertheless makes still sense to use TRIPS as the multilateral benchmark against which several of the problems identified in bilateral and regional agreements are examined and judged. This is justified primarily by the internal balance for which TRIPS is increasingly recognised, especially due to the flexibilities that it leaves WTO Members in designing their IP system to focus on domestic needs. As section 3 below will show, this balance results not least from the objectives and principles of TRIPS, which are amongst the few provisions that are primarily informed by proposals of developing countries in the Uruguay Round. Another reason to use TRIPS as the normative benchmark against which one assesses current trends in international IP norm-setting is that the essentially global consensus reflected in TRIPS is often set out in broad principles, rather than detailed and specific rules. These principles, interpreted in light of utilitarian objectives expressed in Article 7, offer important leeway to respond to societal and technological changes that frequently require law and policy makers to adapt, if not completely re-think, IP protection.

One example shall suffice here: the way we use copyrighted content has completely changed with the advent of the digital, network environment. One the one hand, identical digital copies produced by the click of a mouse and shared through global networks threaten exploitation opportunities of right holders. At the same time, in an age where any use of digital content implicates (temporary) reproductions, the traditional right to authorise reproduction of copyrighted works gives the copyright owner vast powers to control access to and use of such works that goes well beyond the analogue environment in which that right initially operated. These sea-changes triggered some initial responses in the so called 'WIPO internet treaties" 13 in 1996 - which now appear antiquated in the context of social media, user-generated content, and big data. It is naïve to assume that new responses developed today will continue to offer sensible solutions for the technologies that impact on IP tomorrow.

This example shows that IP laws are particularly sensitive to changes in technology and how we use it. While TRIPS does not even attempt to deal with the 'digital revolution' or global communication networks, it generally provides for sufficient leeway to design national systems in accordance with domestic needs, and to adapt them to a changing technological environment. Today's IP provisions in bilateral or regional agreements on the other hand are becoming ever more detailed, technology-specific and prescriptive: They are often transplants of comprehensive IP protection or enforcement approaches that are extracted from the domestic law of the IP-demanding country - without consideration whether they fit into the regulatory and technological environment of the receiving FTA partner country. ${ }^{14}$

In addition, what is transplanted often leaves out the corresponding limits of IP protection and other checks and balances operating in the law of the transplanting country. Add technological specificity, and the resulting transplant is bound to fail in providing any workable solution a

\footnotetext{
${ }^{12}$ Grosse Ruse-Khan, 2016, Chapter 10.

${ }^{13}$ See for example Articles 4, 5, 8, $11 \& 12 \mathrm{WCT}$ and the Agreed Statements to Articles 1(4), 10 in the WCT.

${ }^{14}$ See Correa et al, 2013, 878 .
} 
few years down the line: For example, the detailed and lengthy provisions on the liability of internet services providers (ISPs) which are frequently among those transplanted via FTAs may have addressed most of the issues ISPs, content providers and internet users faced in the times when the EU and the US as the most common exporters of these rules drafted them (about 15 years ago). ${ }^{15}$ These provisions may even be something one can still operationalise so as to cover quite a lot of today's problems - but they hardly will address the core legal questions that field will pose tomorrow. This example articulates the threats which an erosion of policy space via detailed and specific provisions in FTAs brings along - not only for the country importing such detailed rules, but also the country exporting them. Both risk to cast inflexible and uncompromising standards into the hard-to-amend stones an international treaty represents. ${ }^{16}$

In sum, TRIPS-plus provisions (1) represent one side of an often unsustainable trade-off; (2) are sometimes transplants from domestic IP laws which are not well-suited in a different national context; and (3) become ever more detailed and comprehensive - thereby less suitable for a dynamic development of domestic IP laws. Given these problematic consequences that result from the proliferation of FTAs containing TRIPS-plus provisions, this article poses the question how these agreements relate to the generally flexible IP principles and rules operating on the multilateral level, in particular the TRIPS Agreement. Before section 4 scrutinises whether the TRIPS Agreement imposes any limits on inter-se modifications of IP protections amongst WTO Members, the next section reviews the role of two provisions in TRIPS that are central to the analysis in section 4 . These TRIPS provisions express the balancing objectives and public interest principles which operate on the multilateral level.

\section{Articles 7 and 8 TRIPS as Patrons of a Flexible Global IP Framework}

The 'Objectives' expressed in Article 7 and the 'Principles' embodied in Article 8 TRIPS employ, like so many of TRIPS' provisions, open and 'constructively ambiguous ${ }^{\text {'17 }}$ terms which make their application less straightforward. ${ }^{18}$ So far, these provisions have not received any detailed treatment in the comparably scarce IP case-law generated by the WTO dispute settlement body. ${ }^{19}$ In seeking for clarification, this section begins by a brief review of their

\footnotetext{
${ }^{15}$ See the 'notice and take-down' approach in the United States' Digital Millennium Copyright Act (DMCA), as well as the limitations on liability of Internet Service Providers (ISPs) in Articles 12-15 of the E-Commerce Directive 2000/31, and the respective 'transplants' of these approaches in EU and US FTAs, such as the US Korea FTA, Chapter 18 (Intellectual Property Rights), Confirmation Letter (Limitations on Liability for Internet Service Providers), and, to a lesser extent, Article 11.47 of the EU - Singapore FTA.

${ }^{16}$ See generally Correa et al, 2013, 878 .

${ }^{17}$ Terms in TRIPS provisions such as legitimate interests, unreasonable prejudice, discrimination, and unjustifiable often involve constructive ambiguity, opting for a meaning that is broad and ambiguous enough to allow all sides to agree, thereby essentially providing flexibility in their implementation and leaving contested issues to be resolved at a later stage, for example in dispute settlement proceedings, or allowing diverging approaches in domestic implementation; see generally Grosse Ruse-Khan, 2007, 475.

${ }^{18}$ On Article 8 TRIPS see for example Gervais, 2012, 238; Blakeney, 1996, para.3.09; ICTSD \& UNCTAD, 2005, 126; Yusuf, 1998, 13; Ganesan, 2015, 221; Correa, 2007, 108. On Article 7 TRIPS see Slade, 2011, at 414; Pires de Carvalho, 2014, 164-65 \& 191-192; Correa, 2007, 99-103; ICTSD \& UNCTAD, 2005, 131-132; Malbon, Lawson \& Davison, 2014, 194-195.

${ }^{19}$ At the time of writing, the Panel Report in the dispute over Australia's plain packaging measures - which, based on the arguments made by the parties, is likely to involve a significant discussion on Articles 7 and 8 - had not yet
} 
negotiation history in section 3.1. While the travaux préparatoires as such do not form a primary source of guidance in the customary rules on treaty interpretation, ${ }^{20}$ it offers useful insights into understanding key concepts used in Articles 7 and 8, and suggests how these norms intended to operate. The negotiation history also shows important changes that were introduced prior to the final, agreed versions of the text. Given the limited guidance that follows from the ordinary meaning of the broad and ambiguous term central to both Articles 7 and 8, the travaux of these provisions provides us with an initial understanding of the intentions of those who introduced them into TRIPS. Against this background, section 3.1 further explores different possible ways to comprehend and apply these provisions.

Section 3.2 then highlights the common understanding of Articles 7 and 8 all WTO Members expressed in the 2001 Doha Declaration on TRIPS and Public Health. The section will show that, as a subsequent agreement on the interpretation of TRIPS under Article 31 (3) a) VCLT, the Doha Declaration offers important guidance on the function and operation of Articles 7 and 8. As the principal expressions of the object and purpose of TRIPS, these provisions have first and foremost an interpretative function. In this way, they affect the proper understanding of all IP provisions covered by TRIPS.

Section 3.3 shows that in order to give effect both to the substantive meaning and to the interpretative function of Articles 7 and 8, the balancing objective and public interest principles afford significant discretion to WTO Members in their domestic implementation of TRIPS. The call in Article 7 for IP protection and enforcement to achieve utilitarian goals, and the idea of Article 8 to allow WTO Members to protect public interests necessarily implies to have appropriate regard to domestic circumstances. WTO Members should construe their TRIPS obligations, of course within the accepted limits of treaty interpretation under customary international law, accordingly.

Section 3.4 finally focuses on the mounting concerns that have been raised against how policy space and flexibility within TRIPS can be affected by TRIPS-plus rules. All this sets the ground for the core question then addressed in section 4: what role do Articles 7 and 8 of TRIPS play for subsequent IP agreements amongst WTO Members? In particular what limits, if any, follow from these provisions for inter-se modifications in form of the detailed and comprehensive IP provisions commonly found in FTAs?

\subsection{The Basic Idea of Tailoring IP protection to Domestic Needs, and Mindful of the Wider Public Interest}

With the simple title 'Objectives', Article 7 TRIPS states:

The protection and enforcement of intellectual property rights should contribute to the promotion of technological innovation and to the transfer and dissemination of

\footnotetext{
been released to the public. For a detailed discussion on the application of these provisions in earlier TRIPS disputes, see Grosse Ruse-Khan, $2011 \mathrm{a}$.

${ }^{20}$ See Articles 31-33 of the Vienna Convention on the Law of Treaties (VCLT), Vienna, 23 May 1969, 1155 UNTS 331.
} 
technology, to the mutual advantage of producers and users of technological knowledge and in a manner conducive to social and economic welfare, and to a balance of rights and obligations. ${ }^{21}$

The first impression Article 7 conveys is one of a rather dense and convoluted sentence where several (but certainly not all) ${ }^{22}$ objectives of an IP system come together, joined by an overarching notion of balance. In a similar way, an initial look at Article 8 (1), entitled 'Principles', leaves the reader somewhat puzzled. In its final version, this provision states:

Members may, in formulating or amending their laws and regulations, adopt measures necessary to protect public health and nutrition, and to promote the public interest in sectors of vital importance to their socio-economic and technological development, provided that such measures are consistent with the provisions of this Agreement. ${ }^{23}$

Article 8 (2) TRIPS then more specifically allows measures 'to prevent the abuse of intellectual property rights by right holders or the resort to practices which unreasonably restrain trade or adversely affect the international transfer of technology' - but again subjects those to a TRIPS consistency test. The following analysis focuses on Article 8 (1), because as the more general norm, it better captures the core public interest principle that is essential for the object and purpose of TRIPS. As the only horizontal provision within TRIPS that refers to national measures protecting public interests, Article 8 nevertheless does not appear to function as 'general exception clause' akin to, for example, Article XX GATT, since the former includes the requirement that measures must be consistent with TRIPS provisions.

\subsubsection{Negotiation History}

The origins of both Article 7 and 8 (1) lie in a 1989 Communication from India to the Negotiating Group on Trade-Related Aspects of Intellectual Property Rights during the Uruguay Round of trade negotiations. ${ }^{24}$ With regard to Article 7, the Communication emphasised under the heading 'Balance of rights and obligations' that 'international conventions on intellectual property rights clearly recognise the basic principle that there must be a balance between the rights and obligations of the owner of intellectual property. ${ }^{25}$ Some months later, a common proposal by several developing countries on trade related aspects of IP rights within the GATT system ${ }^{26}$ incorporated the idea for such a balance in its Article 1 ('Objectives') as well as in Article 2 ('Principles'): Article 1 (1) of that proposal concerns the

\footnotetext{
${ }^{21}$ Article 7 of the TRIPS Agreement (emphasis added).

${ }^{22}$ The emphasis on innovation incentives and technology transfer implies (for historical reasons explained below) a strong focus on patents and other rights vesting in technology - while especially the objectives of trademark protection and most traditional aspects of copyright protection are not explicitly addressed.

${ }^{23}$ Article 8 (1) TRIPS (emphasis added).

${ }^{24}$ See Uruguay Round of Multilateral Trade Negotiations, Communication from India, Applicability of the Basic Principles of the GATT and of Relevant International Intellectual Property Conventions (5 September 1989, MTN.GNG/NG11/W/39), para.13\&14.

${ }^{25}$ Ibid, para.13. As an example for such a balance, the communication refers to Art.5A PC and the ability for compulsory licensing of patents in cases of abuse.

${ }^{26}$ See Uruguay Round of Multilateral Trade Negotiations, Communication from Argentina, Brazil, Chile, China, Colombia Cuba, Egypt, India, Nigeria, Peru, Tanzania and Uruguay, Applicability of the Basic Principles of the GATT and of Relevant International Intellectual Property Conventions (14 May 1990, MTN.GNG/NG11/W/71). The text therein was later endorsed by two other developing countries, Pakistan and Zimbabwe. It became known as the 'developing countries' proposal'; see Gervais, 2012, 20.
} 
balance between 'the needs for economic, social and technological development of all countries' and 'the rights granted to IPR holders' - while section (2) refers to the 'principal rights and obligations of IP owners' and 'the important inter-relationships between the scope of such rights and obligations and the promotion of social welfare and economic development. ${ }^{27}$ Article 2 in turn contains in section (1) and (3) the following provisions that later appear verbatim in the first official version of the 'Chairman's Draft' (or 'Composite Draft Text') prepared by the Chairman Lars Anell of the Negotiating Group on Trade-Related Aspects of Intellectual Property Rights in July 1990 in order to identify conflicts and overlaps in main proposals made so far:

(1) Parties recognize that intellectual property rights are granted not only in acknowledgement of the contributions of inventors and creators, but also to assist in the diffusion of technological knowledge and its dissemination to those who could benefit from it in a manner conducive to social and economic welfare and agree that this balance of rights and obligations inherent in all systems of intellectual property rights should be observed. (...)

(3) Parties agree that the protection and enforcement of intellectual property rights should contribute to the promotion of technological innovation and enhance the international transfer of technology to the mutual advantage of producers and users of technological knowledge. ${ }^{28}$

The text of Article 7 was further modified in subsequent drafts of 1 October, 25 October and especially of 13 November 1990 where the two sections above are combined into the condensed form Article 7 has now. ${ }^{29}$ While the main text of section (1) was lost when it is merged into section (2), the essential ideas that IP systems should be 'conducive to social and economic welfare' and contribute to a 'balance of rights and obligations' are retained. The lost text of section (1) would have been a more forceful expression that IP rights are also about dissemination and transfer of technology - but this idea was already well captured in section (2) and remains so in the final version of Article 7. In sum, the changes from the developing country proposal to the final version primarily are about reducing overlaps and redundancies but hardly affect the main substance of Article 7 TRIPS. In its essence, the agreed text of the provision indicates the balance that IP protection and enforcement is meant to achieve: for example between producers and users of technology. As this balancing is meant to induce socioeconomic welfare, the TRIPS 'Objectives' express WTO Members' common understanding of IP as a utilitarian tool.

The negotiating history of Article 8 (1) on the other hand reveals that this provision had undergone significant changes from the 1989 Communication of India to the current text. In particular, early versions did not require measures to be consistent with other treaty provisions.

\footnotetext{
${ }^{27}$ Ibid, 7. See also Article 1 (3) \& (4) of that proposal.

${ }^{28}$ Uruguay Round of Trade Negotiations - Chairman's Report to the Group of Negotiation on Goods, Status of Work in the Negotiating Group, Negotiating Group on Trade-Related Aspects of Intellectual Property Rights, including Trade in Counterfeit Goods, (23 July 1990, MTN.GNG/NG11/W/76), 9-10 (Articles 8B.1 \& 8B.3). The draft was first circulated on 12 June 1990 under the chair's sole responsibility; its official version then appeared in July 1990. On this and the overall TRIPS negotiating history and the pivotal role of this draft see Gervais, 2012, 11-31.

${ }^{29}$ See Gervais, 2012, 228-229.
} 
Quite to the contrary, the 1989 Communication referred to the '[p]rimacy of public interest' as a 'principle which is closely related to the balance of rights and obligations'. ${ }^{30}$ Under this principle ' $[\mathrm{t}]$ he state has the inherent right to take measures in public interest abridging the rights of holders of intellectual property rights.' Such measures can be taken 'in pursuance of vital concerns as security, public health, nutrition, agricultural development, poverty alleviation and the like. ${ }^{31}$ The notion of giving primacy to public interest hence suggests an initial intention of crafting a general exception rule. While this idea is difficult to uphold in light of subsequent changes discussed below, the types of public interests mentioned by India and the use of terms like 'vital' match subsequent drafts of Art. 8 and its current text. Conceptually, the public interest principle expressed here appears as a broad version of the 'right to regulate' to protect public interests in a non-discriminatory and proportional manner, recognised under customary international law and nowadays frequently applied in international investment law. ${ }^{32}$

The idea of a general public interest exception that allows to override IP protection then found its way into the first proposal by several developing countries on trade related aspects of IP rights within the GATT system. Yusuf and Ganesan confirm that the main intention was to preserve sufficient flexibility for domestic measures protecting public interests that could come into conflict with IP rights. ${ }^{33}$ In section (2) of Article 2, retaining the entitlement as 'Principles' from India's earlier submission, ${ }^{34}$ the developing country proposal provided that

'[i]n formulating or amending their national laws and regulations on IPRs, Parties

have the right to adopt appropriate measures to protect public morality, national security, public health and nutrition, or to promote public interest in sectors of vital importance to their socio-economic and technological development. ${ }^{35}$

This text reappeared unchanged in the first consolidated 'Chairman's Draft' of TRIPS in July $1990 .{ }^{36}$ In the subsequent drafts of 25 October, 13 and 20 November 1990 however, various versions of a TRIPS consistency test, effectively countering the idea of a general exception provision akin to Article XX GATT, found its way into the text of Article $8 .^{37}$ The travaux, academic writings, as well as recollections of the TRIPS negotiations by key individuals

\footnotetext{
${ }^{30}$ Communication from India, Applicability of the Basic Principles of the GATT and of Relevant International Intellectual Property Conventions, para.14. As discussed above, the idea for a 'balance of rights and obligations' of IP owners arguably served as input to the identical language now found in Article 7 TRIPS.

${ }^{31}$ Ibid. For a discussion on related submissions (again from India) which further refer to the need to balance IP and public interests see ICTSD \& UNCTAD, 2005, 121-122 and Ganesan, 2015, 221.

${ }^{32}$ Philip Morris vs Oriental Republic of Uruguay, Award, 8 July 2016 (ICSID Case No. ARB/10/7), para.287306; Técnicas Medioambientales Tecmed, S.A. v. The United Mexican States, ICSID Case No. ARB (AF)/00/2 (Award, May 29, 2003), para.119; Saluka Investments B.V. v. The Czech Republic, UNCITRAL (Partial Award, 17 March 2006), paras.255, 260, 262; Methanex Corporation v. United States of America, UNCITRAL (Final Award, 3 August 2005) Part IV, Ch.D, para.7.; see also OECD, "Indirect Expropriation" and the "Right to Regulate" in International Investment Law, OECD Working Papers on International Investment - 2004/4 (Sept. 2004), (RLA-238), 5, n.10; and American Law Institute, Restatement (Third) Foreign Relations of the United States (1987), vol. 1, (RLA-257), 712, comment (g).

${ }^{33}$ Yusuf, 1998, 12-13; Ganesan, 2015, 226.

${ }^{34}$ In light of the significant similarities between the 1989 proposal by India and the first developing country draft it appears very likely that the term 'principles' had simply been carried over from India's reference to public interest primacy as a principle that allows to override IP protections.

${ }^{35}$ Communication from Argentina et al, Applicability of the Basic Principles of the GATT and of Relevant International Intellectual Property Conventions, 7 (emphasis added).

${ }^{36}$ Uruguay Round of Trade Negotiations - Chairman's Report (W/76), 9-10.

${ }^{37}$ See Gervais, 2012, 236-237.
} 
involved unfortunately do not offer a clear explanation who requested this change, and why it was accepted. ${ }^{38}$ The following so called 'Brussels Draft' ${ }^{39}$ of December 1990 which already largely resembled the final Marrakesh version of TRIPS then manifested the consistency test as crucial requirement in Article 8 (1). Adding also a necessity requirement in relation to national measures protecting public interests, it stated:

Provided that PARTIES do not derogate from the obligations arising under this agreement, they may, in formulating or amending their national laws and regulations, adopt measures necessary to protect public health and nutrition, and to promote the public interest in sectors of vital importance to their socio-economic and technological development. $^{40}$

While subsequent changes to the text led to slight modifications, the final text of Article 8 (1) retains the TRIPS consistency test as its perhaps most important requirement.

\subsubsection{Balancing Objectives and Public Interest Principles: Exploring Possible Meanings}

What then follows from the negotiation history for construing the meaning of Articles 7 and 8 ? As for the 'Objectives' of TRIPS expressed in Article 7, its convoluted substance appears difficult to grasp and turn into legally meaningful and operational terms of an international treaty. The original intention of the drafters was most likely to highlight the social function of IP protection - in particular for rights vested in technology - as a means to facilitate 'social and economic welfare', rather than being an end in itself. ${ }^{41}$ This finds further support in the preambular recognition that IP rights, even as private rights, serve a utilitarian purpose. ${ }^{42}$ In order to achieve this overarching goal, IP protection must weigh the two intermediate aims of 'promotion of technological innovation' against the 'transfer and dissemination of technology'. This in turn requires a 'balance of rights and obligations' - these being rights and obligations of the 'owners of intellectual property' (and hence not those of WTO Members). ${ }^{43}$ Developing countries had in fact suggested several specific obligations for IP owners as they feared potential abuses, monopoly prices and trade imbalances resulting from the strengthened IP

\footnotetext{
${ }^{38}$ The account of the Brazilian negotiator, Piragibe dos Santos Tarragô, suggests that while Articles 7 and 8 were overall concessions made by developed countries, the 'demandeurs' of TRIPS 'made sure that the eventual measures taken under national legislations, in the light of those objectives and principles, should be consistent with the provisions of the TRIPS Agreement'; see Tarragô, 2015, 250.

${ }^{39}$ Uruguay Round of Trade Negotiations - Trade Negotiations Committee, Draft final act embodying the results of the Uruguay Round of Multilateral Trade Negotiations (Brussels Draft) (3 December 1990, MTN.TNC/W/35/REV.1).

${ }^{40}$ Uruguay Round of Trade Negotiations - Trade Negotiations Committee, Draft final act embodying the results of the Uruguay Round of Multilateral Trade Negotiations (Brussels Draft) (3 December 1990, MTN.TNC/W/35/REV.1), Agreement on Trade Related Aspects of Intellectual Property Rights, including Trade in Counterfeit Goods, 200 (Art.8:1 (Principles) - emphasis added.

${ }^{41}$ See Pires de Carvalho, 2014, 164-65 \& 191-192; Ganesan, 2015, 221.

${ }^{42}$ See the Preamble of TRIPS.

${ }^{43}$ See Communication from India, Applicability of the Basic Principles of the GATT and of Relevant International Intellectual Property Conventions, para.13. The subsequent developing country draft actually contained an Article 5 which was entitled 'Rights and Obligations of Patent Owners' and contained a list of both rights (for example to prevent others from working the invention and to license its use) and obligations (for example to disclose the invention and work it in the territory of the granting state) of patent owners; see Communication from Argentina, Applicability of the Basic Principles of the GATT and of Relevant International Intellectual Property Conventions, 8-9 and the discussion by Ganesan, 2015, 221-222.
} 
rights proposed by developed countries. ${ }^{44}$ While these proposals for explicit obligations have generally not materialized into agreed TRIPS provisions, ${ }^{45}$ the call for IP protection and enforcement to contribute to a balance of rights and obligations of IP owners still stands. The terms that eventually ended up as 'Objectives' in Article 7 therefore represent - together with the public interest 'Principles' of Article 8 - the main TRIPS provisions that are primarily informed by concerns of developing countries. In that regard, they also form an important part of the political bargain that led to the TRIPS Agreement. ${ }^{46}$

Article 7 therefore stands against a one-sided approach to IP protection that solely focusses on the interests of right holders and maximizes their incentives to innovate. In order to promote the overarching goal of socio-economic welfare, domestic IP systems of WTO Members should balance: (1) the intermediate ends of promoting innovation and facilitating technology transfer; (2) the interests of producers and users (of technological knowledge); and (3) the rights and obligations of IP owners. In other words: For IP regulation to serve wider societal goals, it must mediate between IP protection on the one hand, and access to as well as use of protected material on the other. This in turn requires to weigh the interests, rights and obligations of all stakeholders involved. While it is correct that the terms in Article 7 more narrowly focus on rights vesting in technology, this is explained by the particular concerns that triggered its early drafts and should not prevent interpreters from extrapolating the underlying principle of balancing. ${ }^{47}$ All this of course does not offer very much concrete guidance since neither the process of the balancing exercise, nor its outcome, and not even the authority who is meant to conduct this exercise is addressed in Article 7. Before the next two sections clarify these aspects further, the basic meaning of Article 8 (1) needs to be explored.

The negotiation history of Article 8 (1) has shown that what was intended to serve as a general exception clause based on the idea of primacy of public interest over the rights of IP owners had been made subject to the requirement of consistency with other provisions in TRIPS. What then, does this test of consistency with TRIPS mean? While commentators offer various approaches and solutions, ${ }^{48}$ one WTO Panel has tried to tackle this issue. In the European Communities - Geographical Indications (EC-GIs) dispute, the same question arose when the EC essentially argued it should be able to rely on the General Exceptions in Article XX GATT

\footnotetext{
${ }^{44}$ Pires de Carvalho, 2014, 192; Correa, 2007, 92-93; ICTSD \& UNCTAD, 2005, 119. A list of examples for the fears expressed over strengthening IP protection and the need for strong limits as well as obligations imposed on IP owners can be found in the Uruguay Round of Multilateral Trade Negotiations, Communication from Brazil, Negotiating Group on Trade-Related Aspects of Intellectual Property Rights, including Trade in Counterfeit Goods (31 October 1988, MTN.GNG/NG11/W/30).

${ }^{45}$ A notable exception is the disclosure requirement in Art.29 TRIPS - which however does oblige WTO Members to require the applicant to disclose the 'best mode for carrying out the invention' (as proposed by developing countries).

46 See Ganesan, 2015, 221-226, Tarragô, 2015, 250, and generally on political bargains and pressure in the negotiations, Sell, 2003, 108-120. Given that Article 8 (1) has received a significant qualification in form of the TRIPS consistency test, Article 7 probably embodies the main victory among those TRIPS provisions where developing countries appeared as demandeurs.

${ }^{47}$ Correa, 2007, 92 argues that since promoting socio-economic goals and the idea of balance well accepted in WTO law (as expressed for example in the notion of sustainable development in the Preamble to the WTO Agreement), Article 7 is of key relevance for all IP rights. The Preamble to the WCT and the Preamble to the Marrakesh Treaty further support these concepts as general principles in IP law.

${ }^{48}$ See for example Gervais, 2012, 238; ICTSD \& UNCTAD, 2005, 125-27; Yusuf, 1998, 13; Correa, $2007,108$.
} 
to justify a breach of the TRIPS national treatment rule. ${ }^{49}$ It apparently felt that because of the limits imposed through the consistency test in Article 8 (1) TRIPS, a GATT-equivalent general exception should be available, but was missing under TRIPS. In response, the Panel tried to provide a specific explanation why it felt that there is no need for a general exception for public interests within the TRIPS Agreement and why the principles in Article 8 (1) TRIPS - despite its consistency test - are sufficient. It stated:

These principles reflect the fact that the TRIPS Agreement does not generally provide for the grant of positive rights to exploit or use certain subject matter, but rather provides for the grant of negative rights to prevent certain acts. This fundamental feature of intellectual property protection inherently grants Members freedom to pursue legitimate public policy objectives since many measures to attain those public policy objectives lie outside the scope of intellectual property rights and do not require an exception under the TRIPS Agreement. ${ }^{50}$

The Panel hence argued that there is no need for an Article XX GATT-style exception under TRIPS because of the nature of IP rights as negative rights to exclude others from using the protected subject - instead of a positive right against the state to commercialise or use protected subject matter in the market. For the Panel, this feature allows to pursue public policy objectives without interfering with these (negative) rights. Indeed, construing IP rights as negative rights under TRIPS ${ }^{51}$ usually allows governments to impose regulatory controls on the utilisation and exploitation of IP-protected content. TRIPS itself assumes in Article 39 (3) that pharmaceutical and agricultural-chemical products are subject to marketing approval procedures; and WTO Members have long imposed a whole range of measures - from price controls, via labelling requirements, to sale restrictions - that affect the commercial exploitation of IP-protected goods or services. As none of these measures would interfere with an obligation to provide right holders with a negative right to exclude, Article 8 (1) would then have no more than a declaratory function.

However, the realisation of public policy objectives quite often will require interference with the negative right to prevent others from exploiting the protected subject matter. Whenever the public interest demands making protected subject matter available to certain interest groups and/or for a specific purpose, such access or use will conflict with the concept that the right holder can prevent most (commercially relevant) uses of the protected subject matter. In fact, the private rights nature of IP highlighted in the TRIPS Preamble implies that these rights exist primarily in opposition to claims by other private parties (competitors, users) over what is exclusively allocated to the IP owner. It is then equally in the nature of these private rights that in order to realise their overall utilitarian purpose or to give effect to a specific public interest for access to or use of something otherwise protected, their negative, exclusionary character vis-à-vis others must be limited. For example, making affordable generic medicines available to the public while the relevant drug is still under patent protection interferes with the exclusive

\footnotetext{
${ }^{49}$ European Communities - Geographical Indications (EC - GIs), Panel Report (15 March 2005, WT/DS/174R), at para.7.205-207.

${ }^{50} E C-G I s$, para.7.210.

${ }^{51}$ See Articles 11, 14:1-3, 16:1, 23:1, 26:1, 28:1, 39:2 TRIPS which all oblige WTO Members to provide exclusive rights to 'prevent' third parties from using the protected subject matter in various ways.
} 
rights under Article 28 (1) TRIPS. More generally speaking: as soon as the public interest in question cannot be achieved by state-imposed limits on the right holder's exploitation of IP, but requires access to or use of IP by state authorities, public bodies or private parties, the concept of negative rights alone does not ensure that the relevant public interest can be realised.

In these situations, ways and means to limit the exclusive, private IP rights which TRIPS obliges to grant are needed to guarantee a proper balancing of interests. As the TRIPS preamble highlights: these private rights serve a public, utilitarian function. ${ }^{52}$ Those rights hence are not absolute, but subject to various limitations which, for example, authorise a certain (limited) use of the protected subject matter by a (limited) group of beneficiaries. ${ }^{53}$ Of course, TRIPS does contain specific provisions that allow, under certain conditions, WTO Members to introduce such exceptions and limitations to exclusive rights in domestic law. ${ }^{54}$ The very existence of these exception and limitation provisions however raises further questions about the role and function of Article 8 (1) TRIPS: if only the former allow to curtail exclusive rights and the concept of negative rights allows measures that merely affect the (commercial) exploitation of IP-protected goods, what remains for Article 8 (1)? The next section tries to develop an understanding of Article 8 (1) and its consistency test that, in accordance with the principle of good faith in treaty interpretation, ${ }^{55}$ reduces neither of the two to inutility or practical insignificance.

\subsection{Articles 7 and 8 in the Doha Declaration on TRIPS and Public Health}

An initial enquiry into the negotiation history as well as the substance of Articles 7 and 8 has left several questions open. This section shows how the Doha Declaration on TRIPS and Public Health $^{56}$ as well as the Doha Declaration that kicked off a new Round of Trade Negotiations in the $\mathrm{WTO}^{57}$ offered essential guidance on how public interests - such as public health in general and access to medicines in particular - can be given effect in the context of the TRIPS Agreement. These Declarations are equally instructive on the role WTO Members foresee for the balancing objectives of Article 7 TRIPS. As subsequent agreements on the interpretation of TRIPS in accordance with Article 31 (3) (a) VCLT, ${ }^{58}$ they show how WTO Members agreed for Article 7 and 8 to operate.

\footnotetext{
${ }^{52}$ See the discussion in section 1.

${ }^{53}$ Other forms of limiting the exclusivity conferred by IP rights are subject matter exclusions, setting thresholds for obtaining protection, constraining the scope of exclusive rights, and of course limiting the duration of these rights. TRIPS contains rules on most of these issues for most of the relevant IP rights.

${ }^{54}$ Such as Articles 13, 17, 26 (2), 30 and 31 TRIPS.

${ }_{56}^{55}$ See Article 31 (1) VCLT.

${ }^{56}$ Doha Declaration on TRIPS and Public Health.

${ }^{57}$ WTO Ministerial Declaration on the Doha Development Round (20 November 2001, WT/MIN(01)/DEC/1).

${ }^{58}$ In particular the Doha Declaration on TRIPS and Public Health is generally seen as a 'subsequent agreement between the parties regarding the interpretation of the treaty or the application of its provisions' and is thereby equivalent to treaty 'context' - see Abbott, 2002, 491-492; and generally Charnovitz, 2002. For a view that classifies the Doha Declaration as (arguably even more important) 'authoritative interpretation' under Article IX (2) of the WTO Agreement see Shanker, 2002.
} 
The Doha Declaration on TRIPS and Public Health, issued unanimously by all WTO Members in November 2001, is a response to concerns about the impact of strong IP protection on domestic health policies which developing countries had already expressed during the Uruguay Round, and which reached global prominence through the aggressive campaigns by some developed countries and pharma-companies against South Africa and Brazil, which - facing an unprecedented HIV/AIDS epidemic, high prices for drugs and overstretched health budgets adopted national legislation that allowed to limit patent rights in order to facilitate affordable access to medication. ${ }^{59}$ While especially the US and its pharmaceutical industry initially objected fiercely to a Declaration that would highlight the policy space within TRIPS for limiting IP rights to promote affordable access to medicines, the 9/11 attacks on the US and the threat of an anthrax virus epidemic shortly thereafter forced the Bush Administration to rethink its position: it could not plausibly argue against, for example, compulsory licensing to tackle public health issues in the WTO and at the same time threaten Bayer, the patent holder for ciprofloxacin, with the same in order to obtain affordable access to sufficient stocks of this crucial medication against the anthrax virus. ${ }^{60}$ In the course of the consultations at the Doha Ministerial in November 2001, developed countries also realised that any progress on core issues they wished to include in a new Trade Round required concessions on TRIPS and Public Health in exchange. Eventually, the agreement on a 'Declaration on the TRIPS Agreement and Public Health' reached on 14 November 2001 resembled to a large extend earlier proposals made by African states.

The Doha Declaration is usually known for mandating the TRIPS Council to find a solution to the catch-22 situation of those WTO Members that could not benefit from their right to issue a compulsory license (CL) for a patented medicine (due to insufficient domestic manufacturing capacity) and could not rely on imported drugs produced under a CL abroad (something which Art.31 f TRIPS significantly curtails). ${ }^{61}$ It also clarifies the policy space WTO Members enjoy when taking measures to protect public health, primarily by indicating several specific IP tools such as compulsory licensing and parallel importation which provide flexibility for this purpose. Most importantly for this article, paragraph 4 and 5 a) of the Declaration indicate the common intention of WTO Members on how to operationalise the balancing objectives and public interest principles of TRIPS. In paragraph 4, WTO Members

\footnotetext{
${ }^{59}$ South Africa had enacted health reform laws (especially a newly introduced sec. $15 \mathrm{C}$ of the Medicines and Related Substances Control Act) which allowed for compulsory licensing and parallel importation of patented drugs. In response, the US placed South Africa on its Special 301 Watchlist and withdrew tariff preferences; while the Pharma lobby initiated litigation in South Africa, inter alia invoking its right to property under sec.25 of the South African Constitution. The focus of attack in Brazil was its compulsory licensing legislation within the framework of its HIV/AIDS treatment programme which the US challenged to be incompatible with TRIPS (see WT/DS199/39 - Brazil, Measures Affecting Patent Protection). Due to public awareness campaigns and protests by various NGO both cases ended in withdrawal of claims and a public relations disaster for Pharma, the US and others (such as the EU) who had favoured 'patents over patients'. See Hestermeyer, 2007, 11-15; and generally Varella, 2004; Abbott, 2002.

${ }^{60}$ Ironically, it was an offer by CIPLA, an Indian Generic Drug Producer, to supply the US and Canada generic versions of Bayer's Cipro drug that facilitated agreements between Bayer and the Canadian as well as the US Government for significantly lower prices for the anthrax treatment; see Hestermeyer, 2007, 16-17.

${ }^{61}$ The main alternative in form of importing from other countries where the needed medication was not under patent protection was about to disappear as the transition period during which developing countries like India, the biggest producer of generic drugs and potential supplier for other developing countries, were exempted from granting product patent protection for pharmaceuticals was due to expire in January 2005. On the so called 'paragraph 6 system' see generally Matthews, 2004.
} 
agree that the TRIPS Agreement does not and should not prevent Members from taking measures to protect public health. Accordingly, while reiterating our commitment to the TRIPS Agreement, we affirm that the Agreement can and should be interpreted and implemented in a manner supportive of WTO Members' right to protect public health and, in particular, to promote access to medicines for all.

In this connection, we reaffirm the right of WTO Members to use, to the full, the provisions in the TRIPS Agreement, which provide flexibility for this purpose. ${ }^{62}$

Paragraph 5 a) then lists as the first and arguably only flexibility with horizontal application throughout TRIPS that '[i]n applying the customary rules of interpretation of public international law, each provision of the TRIPS Agreement shall be read in the light of the object and purpose of the Agreement as expressed, in particular, in its objectives and principles. ${ }^{, 63}$ Another Ministerial Declaration adopted in Doha, initiating the 'Doha Development Round' of trade negotiations, confirms that the objectives and principles referred to are those 'set out in Articles 7 and 8 of the TRIPS Agreement. ${ }^{64}$

As an interpretative agreement under Article 31 (3) (a) VCLT, the Doha Declaration makes two essential points here: (1) Promoting public health and access to medicines primarily occurs via treaty interpretation and implementation in a way which ensures that TRIPS does not prevent WTO Members from taking domestic measures to this effect. (2) Such interpretation and implementation is first and foremost secured by reading all TRIPS provisions in light of the balancing objectives of Article 7, and the public interests principles expressed in Article 8. For Article 8 (1), this approach based on treaty interpretation and implementation allows to overcome the tension between the provision's core function as a public interest principle and its TRIPS consistency test. Adopting measures necessary to protect public interests, such as public health as general example and access to medicines as a more specific case, does not require a General Exception clause - because TRIPS obligations to protect IP are meant to be construed in a way that does not interfere with WTO Member's right to protect public interests. In this way, the Doha Declaration clarifies the common intention of all WTO Members to retain, within TRIPS, a right to regulate that bears strong resemblance to that right under customary international law. ${ }^{65}$ In order to ensure horizontal application of the public interest principles in Article 8, WTO Members have highlighted their role as forming an essential part of the object and purpose of TRIPS - which in turn should ensure that Article 8 will be considered for any interpretation exercise involving public interests under TRIPS. The utilitarian function of private property rights expressed in the TRIPS preamble further supports such a horizontal role of the public interest principles.

With regard to the balancing objectives expressed in Article 7, the main clarification Doha brings along is to confirm its status as object and purpose of TRIPS - thereby guiding the interpretation of each and every provision in TRIPS. In the words of the Appellate Body, a WTO treaty objective will 'add colour, texture and shading to our interpretation of the

\footnotetext{
${ }^{62}$ Doha Declaration on TRIPS and Public Health.

63 Ibid.

${ }^{64}$ Doha Development Round Declaration, para.19.

${ }^{65}$ Compare for example Philip Morris vs Uruguay, para.287-306 (and the further reference there provided).
} 
Agreements annexed to the WTO Agreement'. ${ }^{66}$ By referring to 'the customary rules of interpretation of public international law', the Doha Declaration links to the accepted principles of treaty interpretation, expressed in Articles 31-33 VCLT. While this is not the place to engage in an in-depth discussion on the role of object and purpose vis-à-vis ordinary meaning and context in a holistic interpretative exercise, ${ }^{67}$ it suffices to state that the balancing objectives of Article 7 have a particularly important role to play whenever construing open and ambiguous terms within TRIPS: even under a 'textual approach' sometimes attributed to the adjudicative organs in the WTO, ${ }^{68}$ the Appellate Body has emphasised that 'where the meaning imparted by the text itself is equivocal or inconclusive, or where confirmation of the correctness of the reading of the text itself is desired, light from the object and purpose of the treaty as a whole may usefully be sought'. ${ }^{69}$ The role of Article 7 is further amplified by the fact that TRIPS is arguably the only WTO Agreement with an operative Article that is entitled 'Objectives' which all WTO Members subsequently agreed to guide the interpretation of 'each provision of the TRIPS Agreement ${ }^{70}$.

In sum, the common intention of all WTO Members expressed in the Doha Declaration significantly advances the proper understanding of the role the balancing objectives in Article 7 and the public interest principles in Article 8 play within TRIPS: By guiding the interpretation of all of its provisions, both norms have horizontal impact. Article 8 (1) primarily ensures that TRIPS obligations which may affect the ability of WTO Members to adopt measures to protect public interests shall be construed 'in a manner supportive of WTO Members' right to protect public health', as well as other public interests recognised in Article 8. This means that TRIPS must be interpreted to allow such measures - to the extent possible in light of the ordinary meaning and context of the relevant TRIPS provisions. The balancing objectives in Article 7 on the other hand inform all TRIPS provisions whose interpretation and implementation calls for policy choices - choices where the utilitarian goals highlighted in Article 7 play a role. This will primarily relate to TRIPS provisions where broad, open and ambiguous terms leave space for more than one defensible meaning and where the treaty interpreter and implementer are called to exercise this discretion in light of the balancing objectives. As the next section will confirm, this balancing 'conducive to socio-economic welfare' can effectively only be performed by national IP law- and policy makers, on the domestic level.

\subsection{Discretion for Balancing in Domestic Implementation of TRIPS}

An open question that remains is how the call for balance in Article 7 as TRIPS' object and purpose can be operationalized? Given that Article 7 uses 'should' rather than 'shall', it arguably does not involve an enforceable obligation for WTO Members to engage in balancing

\footnotetext{
${ }^{66}$ United States - Import Prohibition of Certain Shrimp and Shrimp Products (US - Shrimp), Appellate Body Report, 12 October 1998 (WT/DS58/AB/R), para.153.

${ }^{67}$ See generally Grosse Ruse-Khan, 2010.

${ }^{68}$ See the discussion in Howse, 2000 and Van Damme, 2009.

${ }^{69}$ US - Shrimp, para.114. In that case, sustainable development as one element of the multiple objectives of the WTO agreement guided the interpretation of the Article XX (g) GATT term 'exhaustible natural resources' to include the protection of living (but endangered) species such as sea turtles.

${ }^{70}$ Doha Declaration on TRIPS and Public Health, para.5 a).
} 
exercises when designing their domestic IP laws; nor does it require a particular (balanced) outcome. ${ }^{71}$ Instead, its interpretative function suggests that it primarily enhances flexibility in determining the meaning of broad and open terms that can be found in many TRIPS provisions. Significant room to fine-tune the substance of TRIPS obligations exists for example with regard to terms such as 'expressions' (in contrast to ideas), 'intellectual creations', 'inventions', 'distinctiveness', 'likelihood of confusion', 'inventive step', 'industrial application', 'discrimination', 'ordre public', 'morality', 'legitimate', ‘unjustifiable', 'unreasonable prejudice', 'normal exploitation', 'predominantly', 'exhaustion', 'abuse of intellectual property rights', 'adverse effect' (on 'trade' or 'competition'), 'unfair' ('competition' or 'commercial use'), 'fair and equitable', 'effective', 'adequate', 'proportionality' and 'commercial scale'. 72

If the balancing objectives in Article 7 hence widen the scope for construing the many broad and ambiguous terms in TRIPS in light of the overarching goal of facilitating economic welfare, the central question of course is who should be performing this balancing exercise? Is this a task that is primarily assigned to the WTO's adjudicative organs, in their endeavour to 'clarify the existing provisions of [the WTO] agreements ${ }^{73}$ - or is this for WTO Members to decide, which are arguably much better placed to determine domestic implementation of IP laws in a way that promotes socio-economic welfare? While the role of WTO Panels and the Appellate Body surely is to clarify the meaning of TRIPS, including its more general and ambiguous treaty terms, Article 3 (2) DSU requires this clarification to be conducted 'in accordance with customary rules of interpretation of public international law ${ }^{74}$. Based on Article 31 VCLT, this includes taking due account of the treaty's object and purpose, here in particular Articles 7 and 8. As has been shown above with regard to the public interest principles and as will be shown below regarding the balancing objectives, the substance and meaning of these provisions however demands a strong emphasis on implementation and decision-making on the domestic level.

This is because the idea of balancing the various interests at stake in the regulation of IP necessarily implies responsiveness to the individual circumstances within a WTO Member State: IP rights are territorial and the incentives they are meant to offer, as well as the degree of access they afford, first and foremost have an effect within the domestic setting of the country granting such an IP right. Tailoring the regulation of IP with the aim to generate (and perhaps even optimise) welfare effects can only really work on the domestic level. This in turn necessarily assumes some discretion for Member States as to allow for such tailored responses to the developmental, technological and economic needs of their societies. In particular, the implementation of broader and vague legal terms in TRIPS provisions that bear on the interests to be balanced under Article 7 implies policy space for WTO Members in determining the appropriate balance with the specific domestic circumstances in mind.

Of course, tailored regulation of IP in a domestic economy that attracts foreign investments or serves as an important market for (IP-protected) products abroad has spill-over effects on

\footnotetext{
${ }^{71}$ See also Pires de Carvalho, 2014, 192.

${ }^{72}$ See Articles 6, 9, 10, 13, 15, 16, 17, 20, 27, 30, 31, 39, 40, 41, 42, 46, 61 TRIPS.

${ }^{73}$ Article 3 (2) DSU.

${ }^{74}$ Ibid.
} 
welfare abroad. That however is essentially the result of open markets in a globalised economy, and harmonisation through TRIPS minimum standards is reflecting the IP part of this. Foreign right holders can expect adherence to these standards. But these standards bind states, and require domestic implementation by WTO Members who 'shall be free to determine the appropriate method of implementing the provisions of [TRIPS] within their own legal system and practice'. ${ }^{75}$ These flexibilities to fine-tune such standards into specific protections in national IP laws are an inherent part of the deal agreed in the Uruguay Round - which certainly did not create a global uniform IP law. Tailoring IP protection to domestic needs further corresponds to the recognition of 'the underlying public policy objectives' of domestic IP systems. All this leaves little doubt that the balancing Article 7 calls for can effectively only be conducted on the domestic level.

A further question here will often be to what extent this weighing process has already been performed by the negotiators while drafting TRIPS provisions or is to be conducted on the implementation level by the individual WTO Member States. ${ }^{76}$ While this will depend to some extent on the individual TRIPS provision, some general observations can be made: Firstly, the use of 'should' in Article 7 suggests that the desired effects are not achieved automatically and do not follow as such from any mode of protecting and enforcing IP rights. ${ }^{77}$ Neither are these effects necessarily inherent and fully realised in all the individual TRIPS provisions. Had this been the case, Article 7 would be redundant as an operational provision. ${ }^{78}$ Instead, the concept of balancing in Article 7 makes most sense if understood as a task where the national legislator should consider the objectives and interests mentioned in Article 7 and choose a proper balance when implementing TRIPS. This finds further confirmation in paragraph 5 of the Doha Declaration where WTO Members highlight the 'right of WTO Members to use' Article 7 as a key flexibility within TRIPS. ${ }^{79}$ Such a right to use Article 7 arguably implies that it is in principle up to the WTO Members to conduct the balancing that Article calls for.

Further, the very objective mentioned in Article 7, to advance social and economic welfare, necessitates at least a certain amount of flexibility and policy space to give due regard to the domestic needs of the society. This follows not only from economic theory on IP protection where a crucial common denominator is that in pursuing utilitarian goals via IP protection, one size does not fit all. ${ }^{80}$ Also historical evidence from the IP policies of industrialised countries

\footnotetext{
${ }^{75}$ Article 1 (1) TRIPS.

${ }^{76}$ This issue has been discussed in particular in relation to Article 30 TRIPS: see Canada - Patent Protection of Pharmaceutical Products (Canada - Patents), Panel Report (WT/DS114/R), para.7.26 and Correa, 2007, 101102. While the EC contended that the balancing Article 7 calls for is already fully implemented in the individual provisions of TRIPS, Canada argued for that WTO Members retain policy space to conduct such balancing. The Panel itself tried to accommodate both views to some extent, but did not really resolve the issue.

${ }^{77}$ ICTSD \& UNCTAD, 2005, 126.

${ }^{78}$ This in turn contradicts the principle effectiveness (effet utile) according to which words are in a treaty for a meaning and must be given effect; see United States - Standards for Reformulated and Conventional Gasoline (US - Gasoline), Appellate Body Report (29 April 1996, WT/DS2/AB/R), 21; Japan - Taxes on Alcoholic Beverages, Appellate Body Report (4 October 1996, WT/DS8/AB/R), 96-106 and ICTSD \& UNCTAD, 2005 , 118-119.

${ }^{79}$ See Section 3.2 above. It is worth noting that the Panel Report in Canada-Patents had been issued about a year before the Doha Declaration, and hence could not reflect the emphasis WTO Members placed on Article 7 (and 8) therein.

${ }^{80}$ See the contributions in Kur \& Mizaras, 2011.
} 
in the $19^{\text {th }}$ and early $20^{\text {th }}$ century as well as more recent experience of Asian countries such as Korea, India and China indicates that in order to facilitate technological development and economic welfare, IP policies must be tailored to the circumstances at hand and respond to domestic problems at stake. ${ }^{81}$ All this supports the need for TRIPS to allow for policy space on the domestic level - otherwise a central objective not only of TRIPS, but also of the WTO itself could not be properly implemented.

Indeed, the sustainable development objective referenced in the WTO Preamble and its principle of integration ${ }^{82}$ that mediates between economic, social and environmental concerns equally imply policy space to search for the most appropriate balance on the domestic level. ${ }^{83}$ Due to its ambiguous nature, ${ }^{84}$ the integration principle cannot operate as a norm which constrains state conduct in a way that prescribes one specific integrative outcome. ${ }^{85}$ Hence, states inevitably retain substantial discretion in giving effect to this principle as core element of a sustainable development objective. ${ }^{86}$ International adjudicators have to recognise this domestic policy space to balance economic, social and environmental concerns. They must exercise deference when assessing a disputed implementation of provisions originating from treaties with a sustainable development objective. In China-Rare Earths, the Panel agreed that construing WTO law so as to prevent a Member from taking measures necessary to protect the environment or human, animal or plant life or health is likely to be inconsistent with the sustainable development objective expressed in the WTO Preamble. ${ }^{87}$ This also supports the arguments made in the previous section for construing TRIPS rules in a way that the public interests principles in Article 8 are given effect. In essence, the balancing objectives of Article 7 appear as an IP-specific expression of the sustainable development objective and its principle of integration.

In sum, the notion of balancing interests within the IP system and the overarching aim of promoting socio-economic welfare in Article 7 imply policy space for implementing TRIPS that allows Members to tailor IP protection and enforcement to fit domestic needs. A tailored balancing of interests on the level of domestic implementation finally is not per se curtailed by arguments for legal certainty and legitimate expectations. The latter can be invoked only if such expectations derive from a WTO-conform interpretation, in particular one based on ordinary

\footnotetext{
${ }^{81}$ Elmahjub, 2016, 31-36; Commission on Intellectual Property Rights, 2002, 18-20, and Kumar, 2002, as well as Khan, 2002.

${ }^{82}$ See GabCikovo-Nagymaros Project, Hungary vs Slovakia, Judgment of 25 September 1997, ICJ Reports 1997 , 7-84, para.140. See generally International Law Association (ILA), Declaration of Principles of International Law Related to Sustainable Development (New Delhi, 9 August 2002, Resolution 3/2002 - UN Doc. A/CONF.199/8) and Cordonier Segger \& Khalfan, 2004, 96-171.

${ }^{83}$ See Grosse Ruse-Khan, 2010.

${ }^{84}$ Thomas Wälde notes that the beauty of the concept of sustainable development lies 'in the fact that it is a "principle for all seasons': 'it neither imposes insufferable deprivation of consumption on the present nor disregards the needs of the future. It encompasses humanity, but also nature. It appears to solve irresolvable contradictions. Everybody - from the liberal advocates of the global economy to fundamental environmentalists - can fill the concept with his/her meaning' (emphasis added); see Wälde, 2004, 119.

${ }^{85}$ See Lowe, 1999, 23-24.

${ }^{86}$ Boyle \& Freestone, 1999, 16.

${ }^{87}$ China-Measures Related to the Exportation of Rare Earths, Tungsten and Molybdenum (China - Rare Earths), Panel Report (WT/DS431/R, 26 March 2014) at para.7.111.
} 
meaning or context of a provision. ${ }^{88}$ These two interpretative factors then must be weighed against the TRIPS objectives in favour of a proportional system of IP protection that in principle has to be fine-tuned at the domestic level. Of course, the discretion to balance is limited and cannot amount to a re-writing of individual treaty provisions. These limits are drawn primarily by the parameters of treaty interpretation referred to in Article 3 (2) DSU. To the extent ordinary meaning and context allow for a range of possible meanings, it will be for the national law- and policy makers to interpret and implement TRIPS in a way that is 'conducive to socio-economic welfare' - as determined with regard to the specific domestic circumstances.

Before section 4 discusses the role of both Articles 7 and 8 TRIPS for IP provisions in FTAs amongst WTO Members, the next section shows why this is important and what is at stake: As these FTAs tend to constrain flexibilities otherwise available under TRIPS, they have received criticism from several International Organizations, national parliaments, civil society organizations and academic writers. A common element in the critiques is the call for retaining core flexibilities under TRIPS, in particular those emphasised in the Doha Declaration. This in turn begs the question what role, if any, Articles 7 and 8 TRIPS can play in this regard.

\subsection{Collective Calls to Retain and Protect TRIPS Flexibilities}

As indicated in section 2, obligations in FTAs pertaining to the protection and enforcement of IP rights frequently go beyond the standards of the TRIPS Agreement (commonly referred to as 'TRIPS-plus'). A general trend is for IP provisions in these agreements to become increasingly detailed and comprehensive - often simply aiming to 'transplant' the national IP laws of the demanding country into the legal system of the FTA partner(s). ${ }^{89}$ Such TRIPS-plus rules in FTAs are often subject to criticism..$^{90}$ One central aspect of this critique is the fact that a lot of the TRIPS-plus standards are perceived as reducing or even eliminating the policy space and flexibilities TRIPS allows in the implementation of its obligations. As discussed section 3.2, WTO Members unanimously recognized the importance of some of these flexibilities in the public health context in the Doha Declaration on TRIPS and Public Health. The raise of TRIPS-plus obligations in FTAs then has led to increasing calls for recognizing and protecting a right of WTO Members to exercise their policy space, especially in the context of public health: On the international plane, the WHO emphasized that 'Bilateral trade agreements should not seek to incorporate TRIPS-plus protection in ways that may reduce access to medicines in

\footnotetext{
${ }^{88}$ In India - Patents, the Appellate Body took a clear stand against infusing the concept of legitimate expectations into treaty interpretation - unless the ordinary of the TRIPS terms, in their context, support such expectations; see India - Patent Protection for Pharmaceutical and Agricultural Chemical Products (India - Patents), Appellate Body Report, WT/DS50/AB/R (19 December 1997), para.32-41.

${ }^{89}$ See the discussion in section 2, and Correa et al, 2013, 878 .

${ }^{90}$ See UN Economic and Social Council, 'The Impact of the Agreement on Trade Related Aspects of Intellectual Property Rights on Human Rights - Report of the High Commissioner', (27 June 2001, E/CN.4/Sub.2/2001/13), paras.27-28; United Nations - Human Rights Council, 'Report of the Special Rapporteur on the right of everyone to the enjoyment of the highest attainable standard of physical and mental health' (31 March 2009, A/HRC/11/12) paras.68-93; and generally Drahos, 2003.
} 
developing countries. ${ }^{91}$ Further, the Fifty-seventh World Health Assembly urges WHO Members

as a matter of priority: (...) to take into account in bilateral trade agreements the flexibilities contained in the Agreement on Trade-related Aspects of Intellectual Property Rights and recognized by the Declaration on the TRIPS Agreement and Public Health adopted by the World Trade Organization Ministerial Conference (Doha, 2001). ${ }^{92}$

Similarly, the UN Special Rapporteur on right to health in his 2009 report explains '[f]lexibilities were included in TRIPS to allow States to take into consideration their economic and development needs. States need to take steps to facilitate the use of TRIPS flexibilities. ${ }^{93}$ Because of this essential role of policy space within TRIPS, the Special Rapporteur demands that

'[de]veloping countries and LDCs should not introduce TRIPS-plus standards in their national laws. Developed countries should not encourage developing countries and LDCs to enter into TRIPS-plus FTAs and should be mindful of actions which may infringe upon the right to health. ${ }^{94}$

More recently, the UN General Assembly adopted a resolution where UN member states reaffirm

'the right to use, to the fullest extent, the provisions contained in the World Trade Organization Agreement on Trade-Related Aspects of Intellectual Property Rights (TRIPS Agreement), the Doha Declaration on the TRIPS Agreement and Public Health (...) which provide flexibilities for the protection of public health, and in particular to promote access to medicines for all, ${ }^{95}$

Finally, the September 2016 Report prepared by a High-Level Panel on Access to Medicines, convened by the UN Secretary-General, notes 'instances where undue political and economic pressure have been used to dissuade governments from using [TRIPS] flexibilities' and states that such pressure "violates the integrity and legitimacy of the system of legal rights and duties created by TRIPS'. ${ }^{96}$ It then points to WTO Members 'inalienable duty to protect health', and in this context demands that 'WTO Members must help safeguard the legitimate rights of individual Members to adopt and implement flexibilities in the TRIPS Agreement as reaffirmed by the Doha Declaration.'

\footnotetext{
${ }^{91}$ WHO, Report of the Commission on Intellectual Property Rights, Innovation and Public Health (Geneva, 2006), Recommendation no:

4.26 , http://www.who.int/intellectualproperty/documents/thereport/CIPIHReport23032006.pdf.

${ }^{92}$ WHO, Scaling up treatment and care within a coordinated and comprehensive response to HIV/AIDS, (Geneva, 2004, Resolution WHA57.14, Fifty-seventh World Health Assembly), http://apps.who.int/gb/ebwha/pdf files/WHA57/A57 R14-en.pdf.

${ }^{93}$ United Nations - Human Rights Council (2009), 'Report of the Special Rapporteur on the right of everyone to the enjoyment of the highest attainable standard of physical and mental health', A/HRC/11/12, 31 March 2009, para.96

${ }_{94}$ Ibid, para. 108.

${ }^{95}$ UN General Assembly 'Global health and foreign policy: health employment and economic growth', Resolution A/71/L.41 (8 December 2016), 5 .

96 High-Level Panel on Access to Medicines, Promoting Innovation and Access to Health Technologies, 14 September 2016 (United Nations, Geneva / New York, 2016), 26.
} 
These statements are indicative for the concerns of the international community about not utilising the policy space TRIPS provides, and in particular with TRIPS-plus protections in FTAs that take away this space. References to a 'right to use ${ }^{97}$ TRIPS flexibilities and the "duty to protect ${ }^{98}$ them in order to ensure that public health and other public interests are properly protected point not only to individual entitlements of WTO Members, but also to the utilitarian importance of retaining policy space for domestic IP regulation. The fact that international organisations such as the UN and the WHO frequently utter these concerns suggests a collective interest in retaining TRIPS flexibilities that perhaps even goes beyond any individual rights or duties. Finally, some WTO Members have taken steps, via specific 'TRIPS flexibility safeguard clauses' in FTAs, to ensure that TRIPS rights and obligations in general, or specific TRIPS flexibilities, remain applicable and relevant in the context of their FTAs. ${ }^{99}$

All this begs the question whether those who signed and ratified such FTAs have foregone their 'right to use' TRIPS flexibilities - or whether there are limits to the inter-se modifications that these FTAs represent vis-à-vis the IP provisions (including flexibilities) in TRIPS. In particular, such limits could result from a common interest all WTO Members have as a collective whole in retaining policy space in regulating IP. The next section reviews this issue in light of the core role Articles 7 and 8 TRIPS play as globally accepted objectives and principles whose interpretative function affects all flexibilities in TRIPS.

\section{Limits on Modifying TRIPS Inter-Se}

When considering whether there are any limits on the ability of WTO Members to negotiate away the flexibilities TRIPS provides, the obvious starting point in section 4.1 is to scrutinise TRIPS for any specific conflict clauses that might address this issue. Concluding that the only candidate within TRIPS does in fact not cover the question at issue here, the focus in section 4.2 then shifts to general and customary international law principles that govern the question of modifying treaty rules inter-se. Based on the role of Articles 7 and 8 developed in section 3, the main argument here is that these provisions are of integral character so that derogations from TRIPS flexibilities that are essential for the effective execution of the object and purpose embodied in Articles 7 and 8 will not bind WTO Members to implement IP obligations which prevent them from tailoring IP protections to domestic needs. Rather, they have a right to (re-) establish their own domestic version of a utilitarian balance the objectives and principles of TRIPS broadly call for.

One should add that the issue at stake here is often discussed, on a more general level, in the broader context of fragmentation (or norm overlap and conflict) in international law. ${ }^{100}$ In that

\footnotetext{
${ }^{97}$ UN General Assembly, Resolution A/71/L.41 (2016), 5.

${ }^{98}$ High-Level Panel on Access to Medicines, 2016, 26.

${ }^{99}$ For a comprehensive discussion see Grosse Ruse-Khan, 2011b. While some of these clause go some way to ensure the continued application or at least interpretative relevance of TRIPS flexibilities for IP provisions in FTAs, most make also sure that specific IP obligations of the FTA will prevail. Such clauses, even if they were widely adopted, therefore do not serve as an encompassing solution tot he problem posed here.

${ }^{100}$ See for example International Law Commission, Fragmentation of International Law: Difficulties Arising from the Diversification and Expansion of International Law (Report of the Study Group of the International
} 
context, a commonly agreed methodology would first search, usually via concepts such as systemic integration, for an harmonious interpretation in relation to different norms of international law, binding upon the same states. ${ }^{101}$ Only in case the relation between two or more rules cannot be appropriately addressed by means of interpretation, one would turn to principles and rules for resolving norm conflicts, such as the idea of lex specialis or lex posterior. ${ }^{102}$ For the specific question at issue here, this however is not a sensible and relevant order of analysis: questions about the extent to which parties to a treaty are entitled to modify their rights and obligations under the treaty amongst some of the parties only, in particular by entering into so called inter-se agreements, are necessarily an incidental, preliminary issue. They need to be addressed before one enters into a discussion whether the norms from such an inter-se agreement can be interpreted harmoniously with those of the other agreement - and if not, whether which set of norms prevails in case of a conflict. For this reason, the analysis in this section does not address the extent to which IP provisions in FTAs and those in TRIPS can be interpreted harmoniously; nor does it deal with any conflict norms derived from TRIPS, FTAs, or general international law about which set of norms prevails in a case of a conflict (and indeed, what in fact constitutes a conflict in this context). ${ }^{103}$

\subsection{More Extensive IP Protection under Article 1 (1) TRIPS}

The TRIPS Agreement does not contain an explicit conflict rule which governs its relationship with subsequent agreements: There is no counterpart to Article 2 (2) TRIPS which is limited to the main multilateral IP treaties prior to TRIPS. There however is a provision that in substance is similar to the conflict rules for example in Articles 19 PC, 20 BC which define the relation between the Paris- and Berne Convention vis-à-vis later 'special agreements' amongst the Paris- or Berne Union countries. ${ }^{104}$ In the second sentence of Article 1 (1), TRIPS addresses the issue of additional protection beyond its own standards in the following terms:

Members may, but shall not be obliged to, implement in their law more extensive protection than is required by this Agreement, provided that such protection does not contravene the provisions of this Agreement.

TRIPS hence generally authorizes Members to grant more extensive protection - with the qualification that such protection 'does not contravene the provisions of the Agreement.' ${ }^{105}$ In the context addressed here, the main importance of this qualification lies in its capacity to

\footnotetext{
Law Commission, 13 April 2006, U.N. Doc A/CN.4/L.682) - in the following: International Law Commission, Fragmentation Report (2006), Pauwelyn, 2003.

${ }^{101}$ See in particular Article 31 (3) c) VCLT - discussed extensively in the Fragmentation Report mentioned above, and in Mclachlan, 2005.

${ }^{102}$ See for example Article 30 VCLT on priority in application between subsequent treaties on the same subject matter - also discussed extensively in the Fragmentation Report (2006), and by Pauwelyn (2003).

${ }^{103}$ On these issues see Grosse Ruse-Khan, 2016, in particular Chapters 5, 6, and 7.

${ }^{104}$ Essentially, these provisions make subsequent 'special agreements' on the subject matter covered by the PC and $\mathrm{BC}$ subject to being not contrary to the rules in the existing treaties. Article $20 \mathrm{BC}$ (as well as corresponding provision in Article 22 of the International Convention for the Protection of Performers, Producers of Phonograms and Broadcasting Organizations (Rome Convention) (Rome, 26 October 1961, 496 UNTS 43) adds that alternatively, such agreements must provide 'more extensive rights than those granted by the Convention' and thereby manifests a one-way street towards continuously increasing protections in core areas of international IP law, see generally Kur \& Grosse Ruse-Khan, 2009.

${ }^{105}$ Art.1 (1) TRIPS (emphasis added).
} 
establish a condition on the ability to introduce more extensive IP protection: TRIPS-plus protection must not contravene TRIPS. ${ }^{106}$

The principal question which arises here is whether this TRIPS provision can be understood as a rule governing the relations between TRIPS and subsequent TRIPS-plus FTAs: Article 1 (1) TRIPS directly applies only to the ability of WTO Members to 'implement in their law more extensive protection'. ${ }^{107}$ The distinction between an international agreement (such as a FTA) which requires 'more extensive protection' and introducing such protection in domestic law is a crucial one in IP law: Based on the uniformly accepted notion of territoriality of IP rights, the rights IP owners enjoy and the protection they provide in principle always results from national IP laws - international obligations to introduce 'more extensive protection' would always have to be first transposed into domestic IP laws. ${ }^{108}$ Hence, rules on additional IP protection in a FTA or other international agreement - even if these were found to 'contravene' TRIPS provisions - would arguably not breach Article 1 (1): A plain reading suggests that only the subsequent domestic implementation of TRIPS-plus FTA obligations can violate the noncontravention standard in Article 1 (1). For the purpose of interpretation, the ordinary meaning of this provision thus suggests that the non-contravention standard in Article 1 (1) TRIPS does not function as a conflict rule concerning the relation between TRIPS and subsequent agreements on IP.

Contextual and historical arguments provide support for this view: Article $19 \mathrm{PC}-$ which is explicitly incorporated via the reference in Article 2 (1) TRIPS - contains the same noncontravention standard, but refers to 'special agreements for the protection of industrial property'. Negotiators must have surely been aware of this provision which they included amongst those with which WTO Members must comply. ${ }^{109}$ If they had wished to give the same scope to Article 1 (1) TRIPS, one would expect them to use the same language. The fact that they did not militates strongly in favour of giving effect to the differences in the text of Article 1 (1) of TRIPS: Its scope of operation thus concerns additional protection implemented in national laws - not mandated in international norms.

The negotiation history of Art.1 (1) TRIPS further backs this conclusion. While the Brussels Draft of December 1990 is basically identical to the current text, the earlier W/76 Draft contains a more simple rule entitled 'Freedom to Grant More Extensive Protection' whereby 'nothing in parts III-V of this agreement shall prevent PARTIES from granting more extensive protection

\footnotetext{
${ }^{106}$ For an analysis of this qualification and its implications for the principle of minimum standards, see Grosse Ruse-Khan, 2009.

${ }^{107}$ Art.1 (1) $2^{\text {nd }}$ sentence (emphasis added).

${ }^{108}$ Expressions of the notion of territoriality can be found in a range of international IP treaties, such as Article 5 of the Berne Convention, and Articles 4bis and 6 of the Paris Convention. The fact that in the context of regional integration (such as in the case of the European Union) countries have introduced regional IP rights where one right covers the territory of several states are an exception to this rule. Such exceptions do not result from simply entering into an obligation for 'more extensive protection' in an FTA - unless the parties to this agreement express their clear intention to establish such regional rights.

${ }^{109}$ On the negotiation history of Art.1 (1) TRIPS (whose records however do not seem to offer a conclusive answer on this point), see Gervais, 2012, 11-31; ICTSD \& UNCTAD, 2005, 23.
} 
to intellectual property rights than that provided in this agreement. ${ }^{110}$ This is in contrast to a rule in the same provision that obliges the parties not to derogate from existing obligations under GATT. Predecessors of Art.1 (1) TRIPS hence from the outset did not refer to international agreements granting additional IP protection - while they did so with regard to trade commitments under GATT.

The general international law conflict rule on inter-se modifications amongst some of the parties to a treaty (such as TRIPS) equally supports these findings. Art.41 (1) (a) VCLT allows interse agreements (such as FTAs amongst WTO Members) ${ }^{111}$ if 'the possibility of modification is provided for by the treaty'. While such a possibility may be conditional, commentators demand for an express allowance to modify the treaty. ${ }^{112}$ This aligns with the general position that customary international law, as expressed in the main principles embodied in Article 41 VCLT, applies unless it is specifically contracted out. ${ }^{113}$ Even if one counters that Article 1 (1) implicitly allows states to act together in what this provision authorises them to do in their domestic IP systems, ${ }^{114}$ the no-contravention rule is, as will be further shown below, still of rather different character and addresses different scenarios than the customary principles embodied in Article 41 VCLT. As such, the TRIPS rule on additional protection in national law thus does not bar the application of Article 41 VCLT. Furthermore, equivalent provisions in other WTO Agreements which deal with the ability of WTO Members to enter into subsequent agreements that deviate from WTO law - such as Article XXIV GATT and Article V GATS on additional trade liberalisation - do so by explicitly referring to international treaties rather than domestic rules. ${ }^{115}$

Also the main literature on the topic primarily understands Article 1 (1) $2^{\text {nd }}$ sentence TRIPS as prohibiting additional, TRIPS-plus IP protection in national laws if it contravenes TRIPS provisions. ${ }^{116}$ In conclusion, if additional protection stems from an FTA or other international agreement, it is only the implementation of this protection - not the international treaty rule as such - which is captured by Article 1 (1) TRIPS. This of course still retains a relevant field of operation for this provision as WTO Members must ensure that such additional protection does not contravene TRIPS. However, as it has been argued elsewhere, this qualification does not function to protect (optional) TRIPS flexibilities against WTO Members who decide not to exercise them. $^{117}$

\footnotetext{
${ }^{110}$ See Uruguay Round of Trade Negotiations - Chairman's Report to the Group of Negotiation on Goods, Status of Work in the Negotiating Group, Negotiating Group on Trade-Related Aspects of Intellectual Property Rights, including Trade in Counterfeit Goods, (23 July 1990, MTN.GNG/NG11/W/76), 6.

${ }_{111}$ On the applicability of Article 41 in the TRIPS - FTA relations see section 4.2 below.

${ }^{112}$ Rigaux, Simon, Spanoudis, Weemaels, 2011, 995.

${ }^{113}$ From various ICJ cases where this was held, see in particular Elettronica Sicula S.p.A. (ELSI) (United States of America v. Italy) I.C.J. Reports 1989, 42; see also International Law Commission, Fragmentation Report, 2006, para.185. See the next section for a brief discussion and further references showing that the relevant principles of Article 41 VCLT are indeed commonly considered as customary international law.

${ }^{114} \mathrm{I}$ am indebted for Fernando Bordin for making this point in discussions on the scope of Article 1 (1).

${ }^{115}$ Article V GATS for example states that ' $[\mathrm{t}] \mathrm{his}$ Agreement shall not prevent any of its Members from being a party to or entering into an agreement liberalizing trade in services between or among the parties to such an agreement' if certain conditions are met.

${ }^{116}$ See Stoll, Busche \& Arend, 2009, 81-82; Gervais, 2012, 174. Also Mitchell and Voon conclude that TRIPS does not contain a rule on inter-se agreements; see Mitchell \& Voon, 2009, 597.

${ }^{117}$ Grosse Ruse-Khan, 2016.
} 
In sum, because of its limited scope of application, Article 1 (1) TRIPS as such cannot be employed in order to safeguard the policy space Articles 7 and 8 provide. Therefore, the next step is to consider whether general international treaty law rules can be applied to address the issue of TRIPS-plus provisions limiting policy space provided under TRIPS. And even if one argues that TRIPS-plus FTAs are implicitly covered by Article 1 (1) TRIPS, there is no indication that WTO Members intended the non-contravention standard in this rule to exhaustively cover the relations between TRIPS and subsequent IP treaties between WTO Members. As the next section will show, the core customary law principles embodied in Article 41 hence continue to apply in any case.

\subsection{Inter-se Modifications under Article 41 VCLT}

Article 41 VCLT addresses the question whether and under which conditions two or more of parties of a multilateral treaty may modify the treaty inter se. Since a FTA with provisions on (additional) IP protection concluded amongst two or more WTO Members generally amounts to 'an agreement to modify the treaty [here TRIPS] as between themselves', Article 41 can, in principle, be applied to govern the relation between TRIPS and IP provisions in FTAs between WTO Members. ${ }^{118}$ The main rationale behind Article 41 VCLT is to safeguard a multilateral treaty against modifications by some of its Members only - while at the same time preserving some freedom of states to enter into more specific contractual relations. This balance finds expression in the main criteria for allowing inter-se modifications under Art.41 VCLT: Unless explicitly addressed in the multilateral treaty, modifications are allowed to the extent that they do not affect (i) the rights and obligations of other parties to the multilateral treaty; and (ii) the object and purpose of the treaty as a whole. Applying these criteria depends a lot on the nature of the multilateral treaty: Does it establish separable obligations between individual contracting parties only or obligations owed to the community of parties as a whole? Before addressing these issues, a general question on the applicability of Article 41 VCLT for determining relations between WTO treaties and subsequent agreements amongst WTO Members arises.

\subsubsection{Applicability in the WTO Context}

Although Article 41 VCLT is not part of WTO law, the principles and rules it contains have the status of customary international law and hence generally apply as long as no specific conflict

\footnotetext{
118 Article 41 VCLT requires that two or more of the parties to a multilateral treaty 'conclude an agreement to modify the treaty as between themselves alone' (emphasis added): It follows that only for FTAs where at least one of the contracting parties is not a WTO Member, the general international law rule on inter-se agreements does not apply; see Rigaux, Simon, Spanoudis, Weemaels, 2011, 987; International Law Commission, Fragmentation Report, 2006, 151-152. Hence, in cases where only one FTA contracting party is a WTO Member, the relation between TRIPS and any IP provisions in the FTA for this country is, absent any specific rules, determined by Art.30 (4) VCLT.
} 
norm within the WTO treaties exhaustively governs the matter at issue. ${ }^{119}$ On the specific question of the applicability of Article 41 VCLT in TRIPS - FTA relations, the WTO Appellate Body's findings in Peru - Agricultural Products are decisive. In that dispute, Peru advanced various arguments why a prohibition in Article 4 (2) of the Agreement on Agriculture (AA) ${ }^{120}$ must be either interpreted in light of, or be superseded by, an FTA (allegedly allowing exactly what the AA prohibits) it signed with the complainant, Guatemala. ${ }^{121}$ Rejecting the idea that VCLT treaty interpretation can go as far as to completely turn around the (ordinary) meaning of a WTO rule, the Appellate Body then considered whether the FTA can be invoked as a valid modification of the AA rules. ${ }^{122}$ The Appellate Body was not convinced that the FTA modification should be judged against Article 41 VCLT on inter-se agreements. ${ }^{123}$ It

note[s] that the WTO agreements contain specific provisions addressing amendments, waivers, or exceptions for regional trade agreements, which prevail over the general provisions of the Vienna Convention, such as Article 41. This is particularly true in the case of FTAs considering that Article XXIV of the GATT 1994 specifically permits departures from certain WTO rules in FTAs. ${ }^{124}$

The AB hence concluded that derogations from WTO obligations in FTAs must be judged against Article XXIV GATT and the Enabling Clause to the extent they concern trade in goods; while FTA derogations from commitments on services trade are tested against Article V GATS. $^{125}$

In giving priority to these 'specific' provisions in WTO Agreements over the general VCLT rules, the Appellate Body did two important things: (1) It effectively applied the lex specialis rule as a tool to determine priority in application between competing rules on treaty modifications, including rules outside WTO law, and thereby confirms the relevance of the lex specialis principle for WTO law. ${ }^{126}$ This in itself makes a case for applying general international law principles, in particular those on norm hierarchy and conflict resolution, in WTO dispute settlement. (2) The Appellate Body implicitly opened the door for the application of the more general law once no specific WTO rule exists that applies to the question at issue. This is particularly true when the general rule is part of customary international law: While not all contours of the debates about the role of non-WTO rules within WTO dispute settlement are settled, there is 'little reason of principle to depart from the view that general international law supplements WTO law unless it has been specifically excluded'. ${ }^{127}$ An earlier WTO Panel

\footnotetext{
${ }^{119}$ See Pauwelyn, 2003, 305, 315. In WTO dispute settlement, the Panel in Turkey - Textiles relied on Article 41

(1) VCLT; see Turkey - Restrictions on Imports of Textiles and Clothing Products, Panel Report (31 May 1999, WT/DS34/R), para.9.181.

${ }^{120}$ Agreement on Agriculture (AA) (Marrakesh, 1 January 1995, 1867 UNTS 410).

${ }^{121}$ See Peru - Additional Duty on Imports of Certain Agricultural Products (Peru - Agricultural Products), Appellate Body Report (31 July 2015, WT/DS457/AB/R), para.5.91.

${ }^{122}$ Peru-Agricultural Products, para.5.97.

${ }^{123}$ Ibid, para.5.111.

${ }^{124}$ Ibid, para.5.112 (emphasis added).

${ }^{125}$ Ibid, para.5.113.

${ }^{126}$ For a list of cases where the lex specialis principle is applied to establish a hierarchy primarily amongst different WTO rules, see Cook, 2015, 86-90.

${ }^{127}$ International Law Commission, Fragmentation Report, para.169. The Report continues that '[e]ven as it is clear that the competence of WTO bodies is limited to consideration of claims under the covered agreements (and not, for example, under environmental or human rights treaties), when elucidating the content of the relevant rights
} 
Report also held that '[c]ustomary international law applies generally to the economic relations between WTO Members (...) to the extent that the WTO treaty agreements do not 'contract out' from it., 128

In the TRIPS - TRIPS-plus FTA context, no rule akin to Article XXIV GATT or Article V GATS exists. The amendment or waiver provisions in TRIPS and the WTO Agreement do not apply, as they concern completely different situations. As shown above, Article 1 (1) TRIPS does not apply to inter-se modifications in form of FTAs - so that the door is open to resort to the general rule in Article 41 VCLT. This follows not only as argumentum a contrario from the lex specialis rule which the Appellate Body applied to reject Article 41 VCLT in cases where a more 'specific' WTO provision exists. Earlier WTO Panels have also shown their willingness to consider Article 41 VCLT. ${ }^{129}$ In Peru - Agricultural Products, the Appellate Body hence went beyond the application of the VCLT treaty interpretation rules WTO adjudicators are bound to apply by virtue of Article 3 (2) DSU: it shows that the WTO's 'clinical isolation' from international law - here in form of Article 41 VCLT - does not begin where treaty interpretation ends. General or Customary international law, in particular its rules on priority of application and conflict resolution, does have a place in WTO jurisprudence.

\subsubsection{Operationalising the Principles in Article 41 VCLT}

Unless explicitly addressed in the multilateral treaty, Article 41 allows an inter se modification to the extent that it

(i) does not affect the enjoyment by the other parties of their rights under the treaty or the performance of their obligations;

(ii) does not relate to a provision, derogation from which is incompatible with the effective execution of the object and purpose of the treaty as a whole.

If either of these requirements is not met, the relevant inter-se modification constitutes a breach of the multilateral treaty (here TRIPS) and hence cannot be enforced to the extent of its inconsistency. ${ }^{130}$ While it is rather straightforward to conclude that TRIPS does not provide for an (express) 'possibility of modification' in the sense of Article 41 (1) (a) and that it does not prohibit inter-se modifications, ${ }^{131}$ applying the rules in Article 41 (1) (b) VCLT to IP provisions in FTAs is not. In general terms, TRIPS-plus FTAs as inter-se modifications of TRIPS

(1) may not affect the enjoyment of TRIPS rights or obligations by other (non-FTA) WTO Members;

(2) nor may they modify provisions crucial for the effective execution of TRIPS' object and purpose.

and obligations, WTO bodies must situate those rights and obligations within the overall context of general international law'; ibid, para.170.

${ }^{128}$ Korea - Government Procurement, (19 January 2000) WT/DS163/R, para. 7.96.

${ }^{129}$ Cook, 2015, 93-95.

130 International Law Commission, Fragmentation Report, 2006, 164; for a detailed analysis of the legal consequences of breach, see Pauwelyn, 2003, 310-315.

${ }^{131}$ The conditional allowance of more extensive protection under Article 1 (1) TRIPS does not amount to such a prohibition since (1) it allows such protection unless it contravenes TRIPS provisions; and (2) further deals with domestic implementation of such protection. 
The principal question hence is how these two requirements - which cumulatively must be fulfilled in order for IP provisions in FTAs to be allowed as inter-se modifications of TRIPS can be put into operation in the TRIPS - FTA context.

\subsubsection{Affecting rights or obligations of other WTO Members}

The first requirement expresses the relative effect of the inter-se agreement which must not prejudice the rights of third parties to the multilateral treaty nor add to their obligations (pacta tertiis principle). ${ }^{132}$ The question here is whether IP provisions in FTAs amongst WTO Members can affect the rights and obligations other WTO Members enjoy under TRIPS. This certainly would be the case if the FTA mandates to lower IP protection for right holders of other WTO Members below the minimum standards contained in TRIPS - for example by limiting patent protection to 10 years contrary to Art.33 TRIPS. If however the inter-se modification does not implicate protections of right holders from WTO Members other than the FTA parties, the rights of other WTO Members arguably are not affected: Art.1 (3) TRIPS requires that '[WTO] Members shall accord the treatment provided for in this Agreement to the nationals of other Members.' Hence, lowering patent protection to ten years only for one's own nationals only does not concern TRIPS at all. ${ }^{133}$ Extending this lower standard to the nationals of an FTA partner with the express consent of that country in the FTA does not touch on the rights of other WTO Members as long as their own nationals remain unaffected. ${ }^{134}$

In the typical situation where the FTA extends rather than constrains the minimum standards of TRIPS, it is not easy to conceive a case where third party rights or obligations are affected: Based on the territoriality of IP rights, TRIPS-plus provisions in FTAs and their implementation generally affect the domestic IP regimes of the FTA contracting parties only. Under the obligations to provide most favourite nation (MFN) and national treatment, the right holders of other WTO Members would normally benefit from this additional protection. ${ }^{135}$ In this light, additional IP protection or enforcement agreed inter-se will in principle not add any obligations for other WTO Members; but rather expands their 'right' (under MFN) to demand something beyond the minimum standards of protection.

However, there may be cases where TRIPS-plus protection or enforcement does have a negative impact on other WTO Members: Countries relying on imports of generics or drugs produced under a compulsory licence (for example under the so called 'paragraph six mechanism') ${ }^{136}$

\footnotetext{
132 Rigaux, Simon, Spanoudis, Weemaels, 2011, 1002.

${ }^{133}$ EC - GIs, para.7.148; see also Stoll, Busche \& Arend, 2009, 87, Correa, 2007, 60-61; Hestermeyer, 2007, 198 who all emphasize that TRIPS does not cover the domestic relationship between a Member and its own nationals. ${ }^{134}$ A practical example is Article 224 of the EC - CARIFORUM EPA that introduces a general exception clause which arguably allows for IP-related exceptions beyond the flexibility the so called 'three-step-test' in international IP law provides.

${ }^{135}$ See Article 4 d) TRIPS: distinct to Article XXIV GATT and Article V GATS, TRIPS does not contain an exception from MFN (and national treatment) obligations which would limit additional commitments made in a post-TRIPS FTA to right holders from the FTA partner.

${ }^{136}$ WTO General Council, Amendment of the TRIPS Agreement, Decision of 6 December 2005 (Hong Kong, 8 December 2005, WT/L/641). The 'paragraph six mechanism', so called due to its original mandate in para.6 of
} 
abroad in order to provide their own population with affordable medicines may certainly be affected by TRIPS-plus inter-se modifications if those limit the ability of the manufacturing country to produce and export medicines. Patent term extensions for pharmaceuticals, limits on the grounds for granting compulsory licenses or test data exclusivity periods may disturb access to medicines in all countries relying on the FTA partner agreeing to such TRIPS-plus standards. Similarly, the availability of (affordable) copyright protected material modified for the needs of visually impaired persons (VIPs), such as books in braille, may depend on the existence of exceptions and limitations which allow such modification in the country of origin from where this material then may be exported to countries in need. ${ }^{137}$ Again, a FTA which would affect such exceptions and limitations to produce and export material for VIPs - for example via an exhaustive list of exceptions not including one for VIPs - has an impact beyond the territory of the FTA parties. The same applies for example when the EU includes lists of GIs in FTAs with its trading partners: In those countries, such additional GI protection often will prevent US competitors from continuing to market their dairy products with names similar or identical to GIs (Feta, Gorgonzola or similar) which become exclusive to EU producers by virtue of the FTA. $^{138}$

In general, the availability of all goods or services that rely on exceptions and limitations to IPRs in order to be produced, traded and sold may be affected by FTA protections that undermine reliance on such exceptions or limitations. ${ }^{139}$ Similarly, for companies providing online services that rely on the existence of flexible exceptions and limitations, the ubiquitous nature of the internet can lead to similar results: fewer or more limited exceptions mandated by an FTA in a key domestic market may not only affect the availability of e.g. search services (for images, excerpts of books, etc) in the country introducing such exceptions, but also all other countries unless the service provider is able and willing to target and fine-tune its service in order to cater for different national exception regimes. While this is technologically possible, it may not be economically feasible and may even lead to services being offered globally in accordance with the laws of the most restrictive copyright regime operating in a major market. In sum, international trade, the ubiquitous nature of the internet, global supply chains and dependency on imports of goods affected by IP protection create a scenario where additional IP protection agreed in an FTA certainly can have an impact for other WTO Members.

The main question then is whether there is a right under TRIPS that other (the non-FTA) WTO Members can invoke if they are affected by such additional standards agreed in an FTA? While there certainly is a 'right' to demand adherence to the minimum standards set out in TRIPS, is there a right to a balanced IP system which takes access to- and dissemination of IP protected material sufficiently into account? Does for example India owe it to African WTO Members to retain all possible TRIPS flexibilities in order to ensure the greatest possible access to affordable medicines in these countries? Does TRIPS provide for a right that other WTO

\footnotetext{
the Doha Declaration (n 7), which this General Council decision implements allows exports of medicines produced under a compulsory license into countries with insufficient manufacturing capacities.

${ }^{137}$ See the Marrakesh Treaty, introducing mandatory minimum exceptions and limitations for VIPs.

${ }^{138}$ See the discussion in Part Four, Chapter 1, Section III.

${ }^{139}$ For a detailed analysis on the impact of TRIPS-plus protection on the free movement of information, knowledge and associated goods or services see Grosse Ruse-Khan, 2009, 92-99.
} 
Members utilise all or some of the access and dissemination related flexibilities in the Agreement? In this regard, Article 7 TRIPS states that IP protection and enforcement 'should' be balanced, and promote socio-economic welfare. As shown in section 3, WTO Members in TRIPS express a normative preference, a common goal and expectation, but no hard legal obligation that domestic IP regimes are balancing protection and access. Furthermore, Article 8 (1) TRIPS, as well as other provisions such as Artt.13, 15 (3), 17, 26 (2), 27 (2)\&(3), 30 and 31 TRIPS, allow rather than require WTO Members to adopt measures promoting access and use of IP protected goods or services. Based on the text of the treaty, TRIPS therefore does not establish an obligation for WTO Members to utilise access- and use related flexibilities. It hence also does not create a right of other WTO Members to demand such utilisation - even if this has an impact on access and use in their own territory.

It follows that WTO Members have no right to demand from other Members the full use and implementation of optional provisions in TRIPS that may be limited via a TRIPS-plus FTA. However, they do have a right to use these flexibilities themselves in their own IP system. The Doha Declaration on TRIPS and Public Health makes this explicit in paragraph 4 by reaffirming 'the right of WTO Members to use, to the full, the provisions in the TRIPS Agreement, which provide flexibility for this [public health] purpose.' Section 3.4 has pointed to a range of subsequent statements by international organizations and the community of states which have reiterated this. Based on the general approach within WTO law, including TRIPS, to cover both de facto as well as de jure interferences, ${ }^{140}$ inhibiting the effective ability to exercise a TRIPS flexibility would be sufficient to establish that an inter-se modification 'affect[s] the enjoyment by the other parties of their rights under the treaty'. This right to use TRIPS flexibilities domestically can be undermined by TRIPS-plus rules in an FTA: The case of generic drugs from India seized in transit in the EU on their way to Brazil ${ }^{141}$ offers a good example how border measures which go beyond the minimum standards of TRIPS can affect the ability of other countries to use TRIPS flexibilities at home: to the extent drugs are seized in transit, any potential country of final destination would be effectively barred from relying on international exhaustion or a compulsory licence to import these drugs. Any FTA amongst WTO Members which mandates such transit seizures then undermines the enjoyment of TRIPS rights by WTO Members who intended to import the seized goods.

In more general terms, any form of IP protection and enforcement with extra-territorial effect (such as transit seizures or measures applied to services provided over the internet) may interfere with the ability of other WTO Members to exercise flexibilities as rights under TRIPS in their own law. If such measures are mandated by a FTA, they may be in conflict with the pacta tertiis principle embedded in Article 41 VCLT. One can thus conclude that where a TRIPS-plus inter-se treaty inhibits the ability of other WTO Members to exercise their rights under TRIPS, i.e. to use the TRIPS flexibilities effectively, then such a modification is inconsistent with Art.41:1(b) (i) VCLT.

\footnotetext{
${ }^{140}$ For de facto discrimination under the national treatment obligation see EC - GIs, paras.7.131-7.140; for the general non-discrimination test on patent protection see Canada-Patents, paras.7.100-101.

${ }^{141}$ See generally Jaeger \& Grosse Ruse-Khan, 2009.
} 


\subsubsection{Undermining the effective operation of TRIPS' object and purpose: the nature of TRIPS obligations}

Under the second requirement in Article 41, an inter-se modification may not relate to a provision derogation from which is incompatible with the effective execution of the object and purpose of the treaty as a whole (Art.41 (1) (b) (ii) VCLT). In line with Article 18 VCLT that prohibit acts defeating the treaty's object and purpose after signature but prior to ratification and Article 19 that disallows reservations incompatible with object and purpose, the provision highlights the importance of the treaty's objectives. In the words of the ICJ

'It is also a generally recognised principle that a multilateral convention is the result of an agreement freely concluded upon its clauses and that consequently none of the contracting parties is entitled to frustrate or impair, by means of unilateral decisions or particular agreements, the purpose and raison d'etre of the convention. ${ }^{142}$

Akin to the case of inter-se interferences with the rights and obligations of other parties, this rule builds on the distinction between reciprocal (or synallagmatic) and integral (or interdependent) treaties - a distinction generally recognised in international law. ${ }^{143}$ In a nutshell, multilateral treaties which can be broken down into detachable, bilateral obligations owed between the contracting parties individually and reciprocally belong to the former category of reciprocal treaties. The need for compatibility with the object and purpose of the treaty will here rarely be an obstacle to the conclusion of inter-se agreements. ${ }^{144}$

On the other hand, integral or interdependent treaties are, inter alia, those relating to a common interest of all parties over and above the sum of their individual interests - where the performance of obligations is owed to all parties as a whole (inter omnes partes). ${ }^{145}$ Examples are treaties concerning human rights, human development, world heritage and environmental protection. ${ }^{146}$ Here, an inter-se modification 'constitutes a derogation to the treaty itself and affects all the parties' so that it will much more likely be 'incompatible with the realisation of the object and purpose of the treaty'. ${ }^{147}$ In other words, the purpose of such 'treaties of legislative or administrative character (...) where the utility and effectiveness depends upon uniform application by all parties' will normally be defeated by inter-se deviations. ${ }^{148}$ The origin and rationale for the prohibition in Article 41 VCLT to deviate from provisions essential

\footnotetext{
${ }^{142}$ Reservations to the Convention on the Prevention and Punishment of the Crime of Genocide, Advisory Opinion of 28 May 1951, ICJ Reports 1951, at 21.

${ }^{143}$ See Article 48 (1) of the International Law Commission's Draft Articles on Responsibility of States for Internationally Wrongful Acts, November 2001, Supplement No.10 (A/56/10), which distinguishes between obligations owed to individual states, 'a group of States including that State, and is established for the protection of a collective interest of the group' and those 'owed to the international community as a whole'. See further Barcelona Traction, Light and Power Company, Limited, Belgium v Spain, Judgment of 24 July 1964, ICJ Reports 1970, 32; Pauwelyn, 2003, 52-56 \& 59-60 refers to Articles 30, 41, 53, 58, and 64 VCLT as expressions of this distinction.

${ }^{144}$ Rigaux, Simon, Spanoudis, Weemaels, 2011, 1003-1004.

145 James Crawford, Special Rapporteur, Third Report on State Responsibility (10 March 2000, UN Doc. $\mathrm{A} / \mathrm{CN} / .4 / 507)$, para.92.

${ }^{146}$ Pauwelyn, 2003, 62; Hestermeyer, 2007, 188-190.

${ }^{147}$ Rigaux, Simon, Spanoudis, Weemaels, 2011, 1004.

${ }^{148}$ Draft Convention on the Law of Treaties, Research in International Law under the Auspices of the Faculty of the Harvard Law School, 29(4) (1935) American Journal of International Law (AJIL), 1018.
} 
for the object and purpose of a multilateral treaty hence is its integral character - the pursuit of common interests or values or the establishment of objective regimes or constitutional structures. $^{149}$

Is the TRIPS Agreement, as a specific part of the WTO Agreements, such an integral or interdependent treaty or merely reciprocal in nature? Pauwelyn has argued extensively that the nature of WTO obligations in principle is reciprocal rather than integral - primarily because they constitute a promise to each and every WTO Member individually rather than to the collective whole. ${ }^{150}$ He however concedes that this applies primarily to trade liberalisation commitments - while IP protection rules under TRIPS, as a form of positive integration, can be viewed as integral because they pursue a common interests (such as the promotion of innovation, technological advancement and transfer of technology). ${ }^{151}$ These common interests - which, according to Article 7 TRIPS, the protection and enforcement of IP should promote hence warrant a closer look at TRIPS as a treaty that may go beyond the mere reciprocal exchange of commitments between the individual WTO Members.

One argument to consider TRIPS along with most other international agreements on the protection of IP as merely reciprocal relates to the limited beneficiaries of the protection these treaties confer: IP treaties are - and always have been from their inception - primarily concerned with the protection of foreign right holders from contracting states. For example, the non-discrimination principles as well as minimum standards in the Berne and Paris Convention generally oblige states only vis-à-vis IP owned by foreign right holders, not with regard to purely 'domestic cases'. ${ }^{152}$ This reveals the inherently reciprocal nature of the commitments to protect IP: A state owes it individually and reciprocally to each of the other contracting states to protect the works, inventions and trademarks of their respective right holders. If there was a common, erga omnes partes interest to protect IP - as there is for example a common interest to protect human rights - this interest would demand that all authors and inventors, including (if not primarily) domestic residents and a Member's own nationals, are protected under the conventions.

TRIPS takes the same approach in Art.1 (3) by obliging WTO Members only to protect 'the nationals of other Members'. With regard to the standards of IP protection, it does not move away from the inherently reciprocal nature of international IP obligations. In other aspects however, TRIPS goes beyond serving the bundle of national interests of individual WTO Members to have their right holders protected abroad. These 'integral' aspects concern the objectives of IP protection and enforcement: For the first time in international IP law, the contracting parties in the TRIPS Agreement have constituted the common societal goals IP protection should achieve. The primary textual expression of this shift is Article 7 TRIPS, whereby the 'Objectives' of TRIPS are that IP protection and enforcement

\footnotetext{
${ }^{149}$ See International Law Commission, Fragmentation Report, 160-161. Pauwelyn, 2003, 308-309 shows in detail how the early case-law of the Permanent Court of International Justice (PCIJ) and ICJ, such as the Oscar Chin and Genocide Convention cases, informed and influenced this notion subsequently embodied in Article 41 VCLT.

${ }^{150}$ Pauwelyn, 2003, 69-78. See also Hestermeyer, 2007, 197-199.

${ }^{151}$ Pauwelyn, 2003, 71.

${ }^{152}$ Article 5 (3) BC makes this explicit by stating: 'Protection in the country of origin is governed by domestic law.'
} 
should contribute to the promotion of technological innovation and to the transfer and dissemination of technology, to the mutual advantage of producers and users of technological knowledge and in a manner conducive to social and economic welfare, and to a balance of rights and obligations.

Although not drafted as a hard legal obligation, Article 7 sets out the common objectives IP protection under TRIPS should aim at: promoting innovation, in balance with the transfer and dissemination of technology, overall striving for social and economic welfare. As elaborated in detail in section 3, this is not just hortatory or declaratory language: In the Doha Declaration, all WTO Members confirmed that this provision, together with Article 8 concerning the protection of public interests outside the IP balance, is the primary expression of the object and purpose of TRIPS and therefore shall guide the interpretation and implementation of all other TRIPS provisions. ${ }^{153}$

This function of Articles 7 and 8 TRIPS in setting out the common, collective goals of IP protection hence informs the proper construction of each of TRIPS' rules and thereby finds expression in the individual TRIPS provisions. In this way, it also determines the ability of WTO Members to deviate from these obligations inter-se. FTA rules which nullify TRIPS provisions embodying the common goals set out in Articles 7 and 8 are prohibited under Art.41 (1) (b) (ii) VCLT - as they 'relate to a provision, derogation from which is incompatible with the effective execution of the object and purpose of the treaty as a whole'. ${ }^{154}$ This general finding however does not lead very far: What are these essential elements of a 'constitutional' international IP system that serves the common goals of promoting innovation while providing access to intellectual goods in a balance, as well as to promote public interests? Which, if any, TRIPS provisions represent either the balancing objectives or the public interest principles in a way that WTO Members may not modify them inter-se in an FTA?

An answer depends a lot on the individual circumstances of modifying TRIPS rules via an interse agreement and would generally cover deviations from both minimum protection standards as well as limits to IP protection. For the typical inter-se modification in form of TRIPS-plus rules in a FTA, the TRIPS - as well as incorporated Paris- and Berne Convention - rules on subject matter exclusions (such as Art.9 (2) and 27 (2)\&(3) TRIPS and 2 (8) BC), limits on the scope of protection (as in Artt.13, 17, 27 (1), 30, 31, 33, 39 (3) TRIPS as well as 7, 10 BC) and those dealing with the abuse of IPRs (as in Artt.8 (2), 40 TRIPS and 5A PC) incorporate essential elements deviation from which may often undermine the common goals set out in Articles 7 and 8 TRIPS. Taking the policy space afforded under these provisions away without compensatory measures will make it significantly more difficult for WTO Members to (1) achieve a balanced IP system where Members are still able to tailor IP protection and enforcement to suit its own domestic needs; (2) retain the ability to protect public interests such as public health. A detailed analysis depends on the individual TRIPS-plus provision at stake

\footnotetext{
${ }^{153}$ See para.5 a) of the Doha Declaration.

${ }^{154}$ Mitchell \& Voon, 2009, 598 adopt a similar approach when they refer to public health related flexibilities as reflecting 'the delicate balance agreed among WTO Members' which groups of Members may not tie their hands to determine or restrict via an FTA. The negotiation history of Articles 7 and 8 confirms the importance of these provisions as part of the overall 'TRIPS package'; see Part Five, Chapter 1, Section III. Hestermeyer, 2007, 198 comes to a similar conclusion as to the integral nature of TRIPS - but bases this primarily on the intention of negotiating States to establish an internationally harmonized system of protection.
} 
and hence is beyond the scope of this section. However, Dinwoodie and Dreyfuss have set out a useful framework of an 'international intellectual property acquis ${ }^{155}$ which can well serve as a starting point for examining whether a specific TRIPS-plus FTA provision interferes with a multilateral IP norm in way that undermines the object and purpose of TRIPS: One-sided derogations from the acquis that are not compensated by alternative allowances to achieve a tailored balance or to protect public interests are inherently problematic.

As already highlighted in section 3: the balance of promoting innovation and access set out as the common objective of IP protection and enforcement in Article 7 TRIPS is rather loosely framed. It hence leaves significant discretion for fine-tuning on the domestic level, in accordance with domestic needs. The same applies for measures public interest measures under Article 8: Individual WTO Members are best placed to determine which measures are 'necessary (...) to promote the public interest in sectors of vital importance to their socioeconomic and technological development'. As TRIPS-specific recognition of the right to regulate, also the principles expressed in Article 8 imply discretion on the side of WTO Members. Section 3 has shown how individual TRIPS provisions, interpreted and implemented in light of these objectives and principles, equally leave policy space. This implies that most inter-se deviations from individual TRIPS provisions as such will not necessarily touch the boundaries of the loose multilateral frame set by Articles 7 and 8 TRIPS: As long as the FTA states are still able to achieve a balance they find 'conducive to social and economic welfare' for their domestic IP systems and are able to take measures that protect public interests 'in sectors of vital importance to their socio-economic and technological development', inter-se modifications in FTAs will not undermine the goals of Articles 7 and 8 TRIPS. They will then not amount to a derogation 'incompatible with the effective execution of the object and purpose of the treaty as a whole' prohibited under Article 41 VCLT.

This leaves us with a rather open conclusion on the application of the requirement in Article 41 (1) (b) (ii) VCLT: As a multilateral agreement, TRIPS - and the Paris- and Berne provisions it incorporates - establish an integral framework that is founded on the common goals WTO Members have expressed in Article 7 TRIPS and confirmed in the Doha Declaration. It is also based on the ability to take public interest measures under Article 8, which are equally (if not more) at the heart of the confirmations in paragraph 4 and 5 of Doha. Based on the international law safeguards against inter-se modification of these collective interests of all WTO Members, there are limits to what can be agreed in FTAs: FTA parties must ensure that the IP standards they negotiate do not affect core TRIPS flexibilities derogation from which is incompatible with the effective operation of the object and purpose of TRIPS embodied in its Articles 7 and 8. Hence, flexibilities crucial for the balance which Article 7 establishes, and those crucial to protect public interests under Article 8, must remain untouched. These are flexibilities which are essential for creating a domestic IP system 'conducive to social and economic welfare' and for adopting measures necessary to protect public interests 'in sectors of vital importance to [domestic] socio-economic and technological development'. FTA IP provisions therefore must leave sufficient policy space for this purpose and, based on Article 31 (3) c) VCLT, should be construed in this sense to the extent possible. In cases of specific FTA provisions adding to

${ }^{155}$ See Dinwoodie \& Dreyfuss, 2012, 175-201. 
the protection of right holders' interests, this will often imply a right of the FTA implementing country to draft exceptions and limitations or other compensatory measures necessary for restoring the balance of Article 7 TRIPS, or to give effect to public interests under Article 8. ${ }^{156}$ As soon as these measures are essential for giving effect to TRIPS' object and purpose, the right to adopt them prevails over FTA provisions which cannot be interpreted so as to allow rebalancing under Article 7, and protecting public interests along Article 8. Based on WTO- and general international law, there would hence be no obligation to implement IP protections which cannot be interpreted to allow the policy space described above.

In most instances however, no disregard for a specific TRIPS-plus obligation in a FTA will be required. Usually, adopting measures not explicitly denied or even addressed in the FTA will suffice to re-balance or to protect public interests. In order to illustrate the operation of Articles 7 and 8 as loose constitutional frames of an international IP system anchored in TRIPS, three examples for 'problematic' TRIPS-plus provisions, given in the Report of the UN High-Level Panel on Access to Medicines, ${ }^{157}$ will be discussed here: (1) A prohibition to foresee pre-grant patent opposition proceedings ${ }^{158}$ can be highly problematic from an access to medicines perspective, and significantly limit the ability of third parties to ensure that the patent granting process is properly implementing limits to subject matter as well as the domestic thresholds of novelty, inventive step, and utility (which are commonly applied levers for tailoring patent protection to domestic needs). Countries facing the implementation of such prohibitions would be able to rely on Articles 7 and 8 and 're-balance' their domestic IP system by making postgrant opposition and challenges to patent validity in court proceedings easy, for example by doing away with any presumption of validity.

(2) Obligations to introduce 'patent linkage' where drug regulatory authorities cannot approve a generic version of a patent-protected medicine without the patent owner's consent also significantly curtail the policy space to protect public health and to balance incentives to innovate with access considerations. In order to give effect to Articles 7 and 8 TRIPS, countries facing such linkage provisions in FTAs ${ }^{159}$ could consider introducing options for easy and fast challenges to the validity of the patent 'linked' to generic marketing approval, ideally within the process requesting such approval. They could also carry forward exceptions and especially compulsory licensing from patent law into regulatory approval, so that the producer of generics can obtain marketing approval at least as soon as he has obtained a compulsory licence to make and sell the respective patented product. Unless the measures suggested in (1) and (2) are explicitly prohibited in the relevant FTA, adopting them would not even involve disregarding specific treaty obligations in the inter-se agreement.

The next example however shows that sometimes, TRIPS-plus rules in FTAs can deny core flexibilities essential to ensure that TRIPS does not prevent WTO Members from protecting public health. (3) Limits in FTAs on the grounds for issuing a compulsory licence (for example

\footnotetext{
${ }^{156}$ See also Correa et al, 2013, para.5.

${ }^{157}$ High-Level Panel on Access to Medicines, 2016, 25-26.

${ }_{158}$ Article 16.7(4) US-Singapore FTA; Article 18.8.4 US-Korea FTA.

159 Article 19(5)(3) CAFTA-DR; Article 17(9)(4) US-Chile FTA; Article 15(9)(6) US-Morocco FTA; Article 16(7)(5) US-Singapore FTA; Article 14(8)(5) US-Bahrain FTA.
} 
to national emergencies or tackling anti-competitive practices) ${ }^{160}$ directly clash with one of the core flexibilities highlighted in paragraph 5 of the Doha Declaration. Based on Articles 7 and 8 , WTO Members would have, as a minimum, the right to introduce 'government use' licenses (including for entities authorised by the government) or judicial compulsory licences under Article 44 (2) TRIPS that cover all grounds necessary for a tailored balance and/or the protection of public interests. Alternatively, Articles 7 and 8 TRIPS could be employed as interpretative tools under Article 31 (3) c) VCLT to support a far-reaching reading of 'national emergency' or other ground allowed for compulsory licensing under the FTA. Should those compensatory measure not be sufficient or suitable for the domestic IP system, as a last resort, the FTA contracting state has a right to disregard the FTA obligation which limits the grounds for issuing a compulsory licence.

In summary then, section 4 has shown that Articles 7 and 8 TRIPS, as common object and purpose of the main multilateral treaty on IP protection, do have a role to play in safeguarding TRIPS flexibilities. Where WTO members agree to TRIPS-plus provisions in FTAs the implementation of which eventually prevents achieving the TRIPS balancing objectives and giving effect to public interest principles, those WTO members have a right to 're-balance' their domestic IP system and to introduce public interest measures which are vital to their socioeconomic development. Usually, this will not require disregarding specific IP provisions in FTAs. If the latter however continue to become ever more detailed and comprehensive, the chances increase that at some point in the future, their implementation will derogate from the common object and purpose of TRIPS to an extent that WTO Members who have signed up to them need to go back to the drafting table. As a last resort, they enjoy a right to give preference to the multilaterally agreed Objectives and Principles in TRIPS.

\section{Conclusion: Arguing for a more Resilient Multilateral IP Framework}

Since its inception, the international IP system has continuously transformed itself. After a revolution in the late $19^{\text {th }}$ century where the Paris and Berne Convention as first multilateral treaties superseded a patchwork of a few bilateral or regional agreements, the dynamics changed. In most of the $20^{\text {th }}$ century, we have seen a much more evolutionary development characterised by continuous increasing minimum standards via revisions of the main multilateral treaties, and by expanding their territorial reach to most newly independent states in a post-colonial world. This development - safeguarded by inbuilt mechanisms against erosion of protection $^{161}$ - had set a dynamic agenda towards more IP protection and enforcement within the multilateral system.

From the 1960ies on, increasing opposition by developing countries however prevented further harmonisation upwards; and pushed for more policy space for facilitating technology transfer

\footnotetext{
${ }^{160}$ Article 4(20) US-Jordan FTA; Article 16(7)(6) US-Singapore FTA; and Article 17(9)(7) US-Australia FTA.

${ }^{161}$ See the Paris- and Berne Convention rules that govern the applicability of subsequent revisions (Articles 20-27 $\mathrm{PC}$ and 27-32 BC); and particularly in those rules limiting the ability of the contracting parties to enter into 'special agreements' (Articles 19 PC and 20 BC) which aim to ensure that international IP protection can only increase, not decrease.
} 
and access to essential, IP-protected goods, especially in the context of the New International Economic Order movement. ${ }^{162}$ In order to counter these attempts to weaken the system and to move IP protection and enforcement forward again, a new revolution was necessary. This came in form of shifting multilateral rule-making to the trade forum where IP was only one of several concessions countries were willing to exchange. The resulting WTO/TRIPS Agreement marks the so far highest standard IP demanding countries where able to achieve multilaterally - by covering all main IP rights, adding comprehensive obligations on IP enforcement, and significantly advancing protections in core areas such as patents and trademarks. However, these additions came at a price for IP demanding countries: To secure a consensus on TRIPS, they needed to accept some provisions - such as Articles 7 and 8 TRIPS and several other flexibilities - that primarily embody the demands of developing and IP-importing countries for balancing IP protection with access to protected goods and services.

Ironically, the core of these provisions allow us to identify another revolutionary change: They change the nature of international IP rule-making from mere reciprocal protection of other contracting parties' right holders to a system that is built around common objectives and principles for IP protection: In Article 7 TRIPS, all WTO Members agreed to a balance between the promotion of innovation (via IP protection) and the transfer and dissemination of technology (via limits to protection). In Article 8, they agree that TRIPS allows Members to take measures necessary to protect public interests vital for their development. These collective goals set out a rather loose frame within which WTO Members can implement their TRIPS obligations in light of their domestic needs. More importantly, the 'constitutionalization' of a common objective in TRIPS affects the ability of WTO Members to further change the international IP system in a post-TRIPS world: If taken serious, these constitutional elements of the multilateral system serve as a control so that future amendments do not undermine the common goals expressed in Articles 7 and 8 TRIPS.

In essence, this change in the nature of international IP rule-making may be viewed equally revolutionary as the shift to the trade forum. As the former is essentially a response to demands for the latter, they are interdependent: the global consensus to significantly strengthen the international standards for IP protection and enforcement via TRIPS included, as a quid-proquo, accepting Articles 7 and 8 TRIPS as reflecting the positions of those concerned about the effect the new global standards would have on access to technology, other IP protected goods or services, and on the ability to protect public interests at home. ${ }^{163}$ This quid-pro-quo included to position Articles 7 and 8 as 'Objectives' and 'Principles' of TRIPS. Their role has subsequently confirmed and emphasised by all WTO Members in the Doha Declaration on TRIPS and Public Health. ${ }^{164}$ If one takes the wider international context and the political economy of international IP negotiations since the 1970ies into account, the shift to the trade forum and the codification of common goals of IP protection represent two sides of the same coin: They reflect the continuous struggle between IP-exporting and IP-importing countries about the design of an international framework. Each side represents important forces that are

\footnotetext{
${ }^{162}$ See Grosse Ruse-Khan, 2016, 324-29; Roffe \& Vea, 2009, 79 and generally Patel et al, 2001.

${ }^{163}$ See the review of the negotiation history of Articles 7 and 8 in Section 3.1.1.

${ }^{164}$ See section 3.2.
} 
still driving the system. This adds a political dimension to the legal arguments for taking both sides serious.

Looking at the relationships between TRIPS and TRIPS-plus FTAs in light of the collective goals expressed in Article 7 and the public interest principles of Article 8, we find a complex and sophisticated system at work. The integral nature of the common goals established in TRIPS' object and purpose creates a form of 'resilience ${ }^{, 165}$ of the multilateral system over attempts for inter-se modifications: The multilateral IP system under TRIPS is robust as it does not allow derogating from provisions essential for WTO Members to implement a balance between IP protection and access which Article 7 establishes. As this balance is rather loosely framed in TRIPS, it leaves a lot of room for WTO Members to fine-tune it on the domestic level - or even to modify it via an FTA with other WTO Members. The same goes for the ability to take measures to protect public interests in line with Article 8 - which needs to remain on the table as an option for WTO Members. Again, a lot depends on what Members consider suitable in their domestic context. Hence only grave interferences with the ability to balance and to protect core public interests can be captured under the prohibition to derogate from the common goals set out in Articles 7 and 8 TRIPS. These limits to inter-se modifications nevertheless constitute a true multilateral framework - not simply a set of minimum standards which can be expanded at will. In that regard, TRIPS may be considered as a loose constitutional order on the international IP plane - one that allows WTO Members a right to regulate and to determine the most suitable IP balance for its domestic circumstances.

\footnotetext{
${ }^{165}$ I borrow this instructive term from the subtitle of Dinwoodie's and Dreyfuss' book: A Neofederalist Vision of TRIPS: The Resilience of the International Intellectual Property Regime, 2012. The term here however is understood as toughness, ability to resist or capacity to withstand difficulties - instead of elasticity or flexibility (as Dinwoodie and Dreyfuss primarily appear to understand resilience).
} 


\section{REFERENCE LIST}

Frederick Abbott, 'The Doha Declaration on the TRIPS Agreement and Public Health: Lighting a Dark Corner at the WTO’ (2002) 5 (2) Journal of International Economic Law 469

Michael Blakeney, Trade Related Aspects of Intellectual Property Rights: A Concise Guide to the TRIPS Agreement (Sweet \& Maxwell, 1996)

Alan Boyle \& David Freestone, 'Introduction' in Alan Boyle \& David Freestone (editors), International Law and Sustainable Development: Past Achievements and Future Challenges, (Oxford University Press, 1999)

Steve Charnovitz, 'The Legal Status of the Doha Declarations' 5(2) (2002) Journal of International Economic Law, 211

Commission on Intellectual Property Rights, Integrating Intellectual Property and Development Policy (London, 2002) - online available at http://www.iprcommission.org/graphic/documents/final report.htm

Graham Cook, A Digest of WTO Jurisprudence on Public International Concepts and Principles (Cambridge University Press, 2015)

Marie-Claire Cordonier Segger \& Ashfaq Khalfan, Sustainable Development Law: Principles, Practices \& Prospects (Oxford University Press, 2004)

Carlos Correa, Trade Related Aspects of Intellectual Property Rights (Oxford University Press, 2007)

Carlos Correa, Henning Grosse Ruse-Khan, Josef Drexl, Reto Hilty, Graeme Dinwoodie, Pedro Roffe, Xavier Seuba, Susy Frankel, Annette Kur, Souheir Nadde Phlix, Holger Hestermeyer, Thomas Jaeger, Mor Bakhoum, Matthias Lamping, Bryan Mercurio, Peter Yu \& Jeremy De Beer, Statement of Principles for Intellectual Property Provisions in Bilateral and Regional Agreements, 44(8) (2013) International Review of Intellectual Property and Competition Law, 878

http://www.ip.mpg.de/en/news/principles for intellectual property provisions in bilateral a nd regional agreements.html

Peter Drahos, A Philosophy of Intellectual Property (ANU Press, 2016) - online at https://press.anu.edu.au/publications/philosophy-intellectual-property

Peter Drahos, Expanding Intellectual Property's Empire: the Role of FTAs (Geneva, 2003) http://www.grain.org/rights files/drahos-fta-2003-en.pdf

Graeme Dinwoodie \& Rochelle Dreyfuss, A Neofederalist Vision of TRIPS - The Resilience of the International Intellectual Property Regime (Oxford University Press, 2012) 
E Elmahjub, 'A Case for Flexible Intellectual Property Protection in Developing Countries: Brief Lessons from History, Psychology and Economics', European Intellectual Property Review, Vol. 38 (1), (2016), 31-42

William Fisher, 'Theories of Intellectual Property', in New Essays in the Legal and Political Theory of Property edited by Stephen Munzer (Cambridge University Press, Cambridge, 2001) 168

A V Ganesan, Negotiating for India, in The Making of the TRIPS Agreement: Personal Insights from the Uruguay Round Negotiations, edited by Antony Taubman \& Jayashree Watal, (Geneva, 2015), https://www.wto.org/english/res e/publications e/trips agree e.htm

Daniel Gervais, The TRIPS Agreement - Drafting History and Analysis $4^{\text {th }}$ ed (Sweet \& Maxwell, 2012)

Henning Grosse Ruse-Khan, 'The Role of Chairman's Statements in the WTO' 41(3) (2007) Journal of World Trade 475

Henning Grosse Ruse-Khan, 'Time for a Paradigm Shift? Exploring Maximum Standards in International Intellectual Property Protection' 1(1) (2009) Journal of Trade, Law and Development 56, http://ssrn.com/abstract $=1457416$

Henning Grosse Ruse-Khan, 'A real Partnership for Development? Sustainable Development as Treaty Objective in European Economic Partnership Agreements and Beyond' 13(1) (2010) Journal of International Economic Law 139

2011a: Henning Grosse Ruse-Khan, 'The (Non) Use of Treaty Object and Purpose in Intellectual Property Disputes in the WTO', Max Planck Institute for Intellectual Property \& Competition Law Research Paper No. 11-15, (September 28, 2011), http://ssrn.com/abstract=1939859

2011b: Henning Grosse Ruse-Khan, 'The International Law Relation Between TRIPS and Subsequent TRIPS-Plus Free Trade Agreements: Towards Safeguarding TRIPS Flexibilities?' Journal of Intellectual Property Law, Vol.18, No.2 (2011), 327

Henning Grosse Ruse-Khan, The Protection of Intellectual Property in International Law (Oxford University Press, Oxford, 2016)

Laurence Helfer, 'Regime Shifting: The TRIPs Agreement and New Dynamics of International Intellectual Property Lawmaking' Yale Journal of International Law, Vol. 29, p. 1, 2004, http://ssrn.com/abstract $=459740$

Holger Hestermeyer, Human Rights and the WTO - The Case of Patents and Access to Medicines (Oxford University Press, 2007) 
Bernard Hoekman, William J. Martin and Carlos A. Primo Braga, Preference Erosion: The Terms of the Debate, (World Bank, May 2006) - online available at: http://siteresources.worldbank.org/INTRANETTRADE/Resources/Preferences Intro Terms of the Debate.pdf

Robert Howse, 'Adjudicative Legitimacy and Treaty Interpretation in International Trade Law: The Early Years of WTO Jurisprudence' in J Weiler (Ed), The WTO, the EC and the NAFTATowards a Common Law of International Trade (Oxford University Press, Oxford, 2000), 3570

Justin Hughes, 'The Philosophy of Intellectual Property' Georgetown Law Review Vol.77 (1988-89) 287

Thomas Jaeger \& Henning Grosse Ruse-Khan, 'Policing Patents Worldwide? EC Border Measures against Transiting Generic Drugs under EC- and WTO Intellectual Property Regimes' 40(5) (2009) International Review of Intellectual Property and Competition Law 502

Annette Kur \& Henning Grosse Ruse-Khan, 'Enough is Enough - The Notion of Binding Ceilings in International Intellectual Property Protection' 9(1) (2009) Max Planck Papers on Intellectual Property, Competition \& Tax Law, http://ssrn.com/abstract=1326429

Annette Kur, Vautas Mizaras (Editors), The Structure of Intellectual Property Law - Can One Size Fit All? (Edward Elgar, Cheltenham, 2011)

Zorina Khan, Intellectual Property and Economic Development: Lessons from American and European History, (Commission on Intellectual Property, 2002) - online available at http://www.iprcommission.org/graphic/documents/study papers.htm

Nagesh Kumar, Intellectual Property Rights, Technology and Economic Development: Experiences of Asian Countries. (Commission on Intellectual Property, 2002) - online available at http://www.iprcommission.org/graphic/documents/study papers.htm

Vaughan Lowe, 'Sustainable Development and Unsustainable Arguments' in Alan Boyle \& David Freestone (editors) International Law and Sustainable Development: Past Achievements and Future Challenges (Oxford University Press, Oxford, 1999)

Justin Malbon, Charles Lawson \& Mark Davison, The WTO Agreement on Trade Related Aspects of Intellectual Property Rights - A Commentary (Edward Elgar, Cheltenham, 2014)

Campbell Mclachlan, 'The Principle of Systemic Integration and Article 31(1)(c) of the Vienna Convention' 54(2) (2005) International and Comparative Law Quaterly, 279 
Duncan Matthews, 'WTO Decision on Implementation of Paragraph 6 of the Doha Declaration on the TRIPS Agreement and Public Health: A Solution to the Access to Essential Medicines Problem?' (2004) 7 (1) Journal of International Economic Law 73

Andrew Mitchell \& Tania Voon, 'Patents and Public Health in the WTO, FTAs and Beyond: Tension and Conflict in International Law' 43(3) (2009) Journal of World Trade 571

Nuno Pires de Carvalho, The Trips Regime of Patents and Test Data $4^{\text {th }}$ ed, (Kluwer, 2014)

Surenda Patel, Pedro Roffe and Abdulqawi Yusuf (editors) International Technology Transfer, The Origins and Aftermath of the United Nations Negotiations on a Draft Code of Conduct (Kluwer, New York, 2001)

Joost Pauwelyn, Conflict of Norms in Public International Law, (Cambridge University Press, Cambridge, 2003)

Kal Raustiala, 'Density \& Conflict in International Intellectual Property Law' 31(6) (2006), University of California, Los Angeles School of Law Research Paper http://ssrn.com/abstract $=914606$

Anne Rigaux, Denys Simon, Joanna Spanoudis, Edith Weemaels, 'Article 41 - Agreements to modify multilateral treaties between certain parties only' in The Vienna Convention on the Law of Treaties Vol. II, edited by Oliver Corten \& Pierre Klein (Oxford University Press, Oxford, 2011)

Pedro Roffe \& Gina Vea 'The WIPO Development Agenda in an Historical and Political Context' in The Development Agenda: Global Intellectual Property And Developing Countries, edited by Neil Netanel (Oxford University Press, Oxford, 2009)

Susan Sell, Private Power, Public Law: The Globalisation of Intellectual Property Rights (Cambridge University Press, Cambridge, 2003)

Daya Shanker, 'The Vienna Convention on the Law of Treaties, the Dispute Settlement of the WTO and the Doha Declaration on the TRIPS Agreement' 36(4) (2002) Journal of World Trade 763

Alison Slade, 'Articles 7 and 8 of the TRIPS Agreement: A Force for Convergence within the International IP System', 14(6) (2011) The Journal of World Intellectual Property, 413

Michael Spence, 'Justifying Copyright' in McClean and Schubert (editors), Dear Images: Art, copyright and culture (Manchester: Ridinghouse, 2002), 389

Piragibe dos Santos Tarragô, Negotiating for Brazil, in The Making of the TRIPS Agreement: Personal Insights from the Uruguay Round Negotiations, edited by Antony Taubman \& 
Peter-Tobias Stoll, Jan Busche \& Katrin Arend, WTO - Trade-Related Aspects of Intellectual Property Rights (Brill, 2009)

Isabelle Van Damme, Treaty Interpretation by the WTO Appellate Body (Oxford University Press, 2009)

Marcelo Dias Varella, 'The WTO, Intellectual Property and Aids - Case Studies from Brazil and South Africa' (2004) 7(4) Journal of World Intellectual Property 523

Thomas Wälde, 'Natural resources and Sustainable Development: From "Good Intentions" to "Good Consequences"” in International Law and Sustainable Development Nico J Schrijver \& Friedl Weiss (Martinus Nijhoff, 2004)

Abdulqawi Yusuf, 'TRIPS: Background, Principles and General Provisions', in Intellectual Property and International Trade, edited by Carlos Correa and Abdulqawi Yusuf (Kluwer, New York, 1998) 